\title{
Cancer Treatment-Related Lung Injury
}

\author{
Vickie R. Shannon
}

\section{Contents}

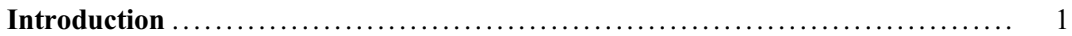

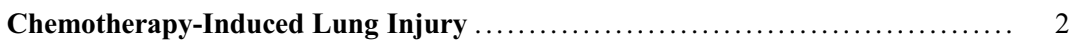

General Principals ................................................ 2

Lung Injury Associated with Cancer Immunotherapies ................... 15

Immune Checkpoint Blocking Agents ................................ 15

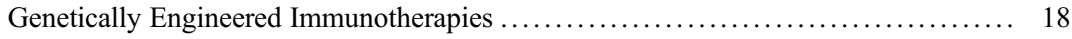

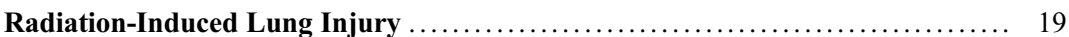

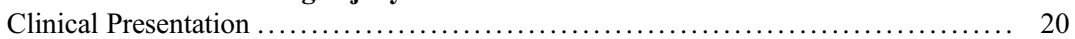

Radiation Recall Pneumonitis .......................................... 21

Other Manifestations of Radiation-Induced Lung Injury .................... 21

Management of Radiation-Induced Lung Injury $\ldots \ldots \ldots \ldots \ldots \ldots \ldots \ldots \ldots \ldots \ldots \ldots \ldots \ldots \ldots \ldots \ldots \ldots$

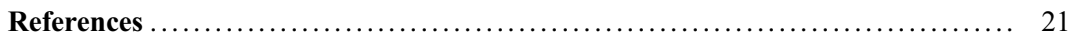

\section{Keywords}

Drug-induced lung disease $\cdot$ Lung injury · Toxicity $\cdot$ Chemotherapy $\cdot$ Immunotherapy $\cdot$ Targeted therapy $\cdot$ Radiation $\cdot$ Pneumonitis $\cdot$ Malignancy $\cdot$ Pulmonary $\cdot$ Interstitial pneumonitis - Pleural effusions · Respiratory · Cancer treatment

\footnotetext{
Author Contributions: VS: conception and design, acquisition of radiological data, drafting the chapter, critical revision of intellectual content, and final approval of the version to be published

\section{R. Shannon $(\bowtie)$}

Department of Pulmonary Medicine, Division of Internal Medicine, The University of Texas MD Anderson Cancer Center, Houston, TX, USA

e-mail: vshannon@mdanderson.org
}

\section{Introduction}

Recent advancements in the understanding of cancer biology have fueled a new era in anticancer therapeutics that extends beyond the class of conventional cytotoxic chemotherapy and radiation therapy regimens. Strategies that exploit the cancer genome in the development of molecular-targeted therapies and schemes that harness the immune system to tilt immune equilibrium in favor of enhanced tumor killing have rapidly emerged as standard of care for patients with a variety of malignancies and have joined the ranks of cytotoxic drugs in the medical management of some cancers. Each class of cancer therapeutics has been limited by a unique spectrum of toxicities that may target the lung parenchyma, pleura, and/or 
pulmonary circulation. Although drug-related adverse events within the thoracic cavity are infrequent relative to other organ systems, they are an important source of severe and life-threatening toxicity. Therefore, failure to recognize early clinical clues may have catastrophic consequences. Respiratory distress is a frequent reason for ICU transfer in cancer patients and is attributable to infectious causes associated with cytotoxin-related immune suppression in most cases. In addition, cytotoxic therapies as well as the molecular-targeted and immune therapies are reported to cause a unique spectrum of noninfectious complications that affect the lung parenchyma, pleura, and vascular structures. For example, interstitial pneumonitis is an important sequela of cancer therapy and frequent reason for drug withdrawal [1-9]. Inhibitors of antiangiogenetic pathways are a source of severe vascular side effects within the lungs, including thromboembolic events and pulmonary hemorrhage. The cardiotoxic effects of these agents as well as the Bcr-Abl inhibitors may result in pulmonary edema associated with congestive heart failure $[10,11]$. The emergence of pleural and pericardial effusions owing to Bcr-Abl inhibition has also been described [12-16].

Familiarity with established common adverse lung events and management of potentially lifethreatening complications relating to conventional and new anticancer agents are essential for treating clinicians, including the ICU staff, oncologists, and organ specialists. This chapter provides an update and review of the clinical and pathophysiologic findings associated with specific notorious cancer pharmacotherapies and presents evidence-based algorithms, where available, in the management of thoracic complications associated with chemotherapeutic agents and radiation therapy.

\section{Chemotherapy-Induced Lung Injury}

\section{General Principals}

\section{Incidence and Risk Factors}

Pneumotoxicity may be predictable and dose dependent with some agents (busulfan, bleomycin, nitrosoureas). Other reactions are idiosyncratic and dose independent, occurring as a result of immunemediated processes, bioactivation, or toxic drug metabolites. The frequent use of complex multidrug and multimodality regimens and overlapping clinical and radiographic manifestations of lung injury caused by drug toxicity, infection, and cancer relapse render precise estimates difficult. Predisposing factors, including patient age, tobacco use history, cumulative dose, renal dysfunction, oxygen therapy, and preexisting lung disease, may influence the incidence, severity, and latency period of lung toxicity following drug exposure. The significance of these risk factors varies with individual agents within a particular drug class and across drug classes. For example, preexisting fibrosis is a significant independent risk factor in the development of severe and accelerated pulmonary toxicity following therapies with conventional cytotoxic therapies such as gemcitabine, oxaliplatin, amrubicin, bleomycin, methotrexate, and the molecular targeted therapies everolimus, temsirolimus, erlotinib, gefitinib [17-21]. Whether prior lung fibrosis potentiates toxicities associated with the class of drugs known as immune checkpoint inhibitors has not been established. Cancer agents within one therapeutic class may produce histopathologic patterns of lung injury with widely varying frequencies. For instance, pulmonary hypertension is a well-established adverse event following the Bcr-Abl inhibitor, dasatinib, but extremely rare among other agents within this class of drugs. Thus, estimates of the incidence of lung injury caused by individual chemotherapeutic agents vary broadly. Reported estimates are included in discussions of individual agents.

\section{Diagnosis}

Pneumotoxicity associated with chemotherapeutic agents represents a diagnostic conundrum. Toxicity is typically assessed through clinical, radiographic, and histopathologic studies, although no single abnormality is pathognomonic. Biomarkers and laboratory studies are not sufficiently sensitive to distinguish drugrelated lung injury from competing diagnoses. Histopathologic features of chemotherapyinduced lung injury are not specific for DILD and can be seen in a wide variety of clinical 
contexts and competing diagnoses, including pneumonia, congestive heart failure, and cancer progression. High-resolution CT (HRCT) scans may detect early abnormalities; however, imaging findings are nonspecific. Interstitial and mixed alveolar-interstitial abnormalities are frequent findings on computed tomography (CT). These abnormalities appear as bilateral (may be asymmetrical) reticular markings, septal thickening, and ground-glass opacities that typically localize to the subpleural and lower lung zones. Radiographic manifestations of pulmonary fibrosis, including traction bronchiectasis and honeycombing, herald the onset of end-stage lung disease. Other findings, including nodular lesions, pleural effusions, and lymphadenopathy, may be confused with cancer progression.

Bronchoalveolar lavage (BAL) with or without lung biopsies may be helpful in excluding competing diagnoses of infection or background disease. BAL findings of increased numbers of lymphocytes, eosinophils, fibroblasts, and dysplastic type II pneumocytes may aid in the diagnosis of chemotherapy-induced lung injury; however, none of these findings are diagnostic. Decreased CD4/CD8 ratios on BAL fluid are also supportive findings; however, ratios vary widely and cannot distinguish sufficiently between drug-induced and other causes of ILD [22-24]. The diagnosis of DAH is supported by findings of progressively bloody BAL samples on sequential aliquots and/or cytologic evidence of increased numbers of hemosiderin-laden macrophages on BAL fluid. Serum elevations of the WBC count, erythrocyte sedimentation rate, and C-reactive protein are also common but nonspecific findings. Toxicity to the lung parenchyma is usually signaled by a reduction in the diffusing capacity (DLCO). With disease progression, a restrictive ventilatory defect is seen [25-28]. Alteration in DLCO is generally accepted as the most sensitive parameter in assessing drugrelated injury, although its predictive potential for the detection of early change has been variable. Irreversible changes in lung function are seen with end-stage lung disease. In earlier stages, normalization of pulmonary function may occur, typically within 2 years of toxin exposure $[25,27,29,30]$.
The diagnosis of DILD is, therefore, based on the exclusion of competing causes in the context of a compatible clinical presentation and temporal relationship between the administration of the suspected drug and onset of symptoms. Measureable improvements in clinical signs and symptoms following drug withdrawal and/or recrudescence of disease with drug rechallenge are supportive of the diagnosis. Delayed toxicities, occurring months to years after drug withdrawal (gentamycin, bleomycin, busulfan) and disease progression despite discontinuation of the offending agent (immune checkpoint inhibitors), are diagnostically challenging features of some agents. Drug rechallenge is justified only in a minority of patients, and its use as a diagnostic tool is discouraged.

\section{Clinical Presentation}

Manifestations of pneumotoxicity are nonspecific and protean. Most commonly, symptoms of cough (typically nonproductive), dyspnea, hypoxia, and low-grade fever develop insidiously over weeks to months after drug exposure. Fulminant disease, which may rapidly progress to respiratory failure and acute respiratory distress syndrome (ARDS), is also seen. Symptom onset varies with individual drugs and may be classified into acute (within hours to days of drug exposure), early (within the first 6 months of drug exposure), and late (6 months or more after exposure) time periods. Delayed pulmonary fibrosis, occurring months to years after exposure to bleomycin, busulfan, cyclophosphamide, gemcitabine, and the nitrosoureas as a late manifestation of DILD, has also been described [31-33].

\section{Histopathologic Features of DILD}

The response of the lungs to drug-related adverse events results in stereotyped histopathologic patterns of lung injury. Drug-induced interstitial lung diseases (DILD) (nonspecific interstitial lung disease, NSIP; pulmonary fibrosis, PF; hypersensitivity reactions, HP; sarcoid reactions) and alveolar processes (diffuse alveolar damage, DAD; diffuse alveolar hemorrhage, DAH; eosinophilic pneumonias, EP; noncardiogenic pulmonary edema, NCPE; alveolar proteinosis) 
are the most frequent histopathologic patterns of response to standard chemotherapeutic agents as well as molecular-targeted therapies and immunomodulating agents. Pleural diseases (pleural effusions, fibrosis), drug-induced vascular disorders (thrombosis, pulmonary hypertension, pulmonary veno-occlusive disease, PVOD), airway disorders (bronchospasm, infusion reactions), and mediastinal diseases (lymphadenopathy, fibrosis) have also been described, particularly following molecular-targeted and immunomodulating therapies. Finally, immune suppression following conventional and targeted therapies as well as immune activation triggered by immunomodulating agents may incite a variety of opportunistic pneumonias. The often lifethreatening pneumonias that may emerge in the setting of immune suppression are discussed elsewhere.

\section{Specific Clinical and Histopathologic Patterns of DILD}

Interstitial Lung Disease. Interstitial pneumonitis is one of the major patterns of lung injury following systemic cancer therapies. This pattern of lung injury may arise from direct cytotoxicity, oxidative stress, and immune-mediated mechanisms. Pneumonitis may be stratified into six major categories according to clinicoradiographic and histopathologic findings: (1) nonspecific interstitial pneumonitis, (2) organizing pneumonia, (3) hypersensitivity pneumonitis, (4) diffuse alveolar damage/acute respiratory distress syndrome, (5) diffuse alveolar hemorrhage, and (6) eosinophilic pneumonia. Characteristic imaging features and the cancer agents that have been implicated in the development of category of lung injury are listed in Tables 1 and 2 . The diagnosis of drug-induced ILD requires a high index of suspicion. Individual agents may elicit multiple patterns of lung injury. Lung injury patterns within a single class of drugs may vary widely. Furthermore, there are pathognomonic imaging findings or histopathologic markers that distinguish drug-induced ILD from other causes. Drug interruption with or without the addition of systemic corticosteroids is the mainstay of treatment of drug-related IP. Optimal dose, timing, and duration of steroids in this setting have not been well established; however, $0.5-1 \mathrm{mg} / \mathrm{kg} / \mathrm{day}$ of prednisone or its equivalent is generally given for 8-12 weeks. Although most patients present with mild disease, any of the ILD injury patterns may progress to pulmonary fibrosis, particularly with acute and fulminant presentations of ILD, such as that seen in the setting of ARDS/DAD.

Nonspecific Interstitial Pneumonitis (NSIP). Nonspecific interstitial pneumonitis and organizing pneumonia (OP) are the most common morphologic patterns of interstitial lung disease following systemic chemotherapy, including the molecular-targeted and immune checkpoint inhibitor therapies. Dry cough and progressive dyspnea, developing insidiously, over weeks to months following drug exposure are notable clinical features of both syndromes. Diffuse ground-glass and reticular opacities with peribronchovascular predominant fibrosis and sparing of the subpleural space help to distinguish NSIP from other forms of pulmonary fibrosis (Fig. 1). However ground-glass consolidations localizing to the lung periphery and bibasilar areas are also frequently seen, particularly in late forms of disease, rendering these diagnostic clues imperfect [34]. An extensive list of conventional cytotoxic chemotherapies has been linked to the development of NSIP. These most commonly include the cytotoxic antibiotics (bleomycin, mitomycin), the nitrosoureas (BCNU, CCNU), other alkylating agents (busulfan, cyclophosphamide), antimetabolites (methotrexate, gemcitabine, procarbazine, cytosine, arabinoside), the podophyllotoxins (etoposide), taxanes (paclitaxel), and the antiangiogenesis inhibitors (thalidomide, pomalidomide, lenalidomide). Among the molecular-targeted therapies, cetuximab, erlotinib, gefitinib, brentuximab, panitumumab, obinutuzumab, dasatinib, brigatinib, and m-tor inhibitors, everolimus and temsirolimus, are most frequently implicated. NSIP is also triggered by the programmed cell death-1/programmed cell death-ligand 1 (PD-1/ PD-L1) inhibition and, to a lesser extent, the anti-cytotoxic $\mathrm{T}$ lymphocyte antigen (antiCTLA-4) immune checkpoint inhibitors.

Organizing Pneumonia. The histologic hallmark of organizing pneumonia (OP) is fibrin plugs within the lumens of distal airways with associated chronic inflammation. This finding, coupled with patchy 


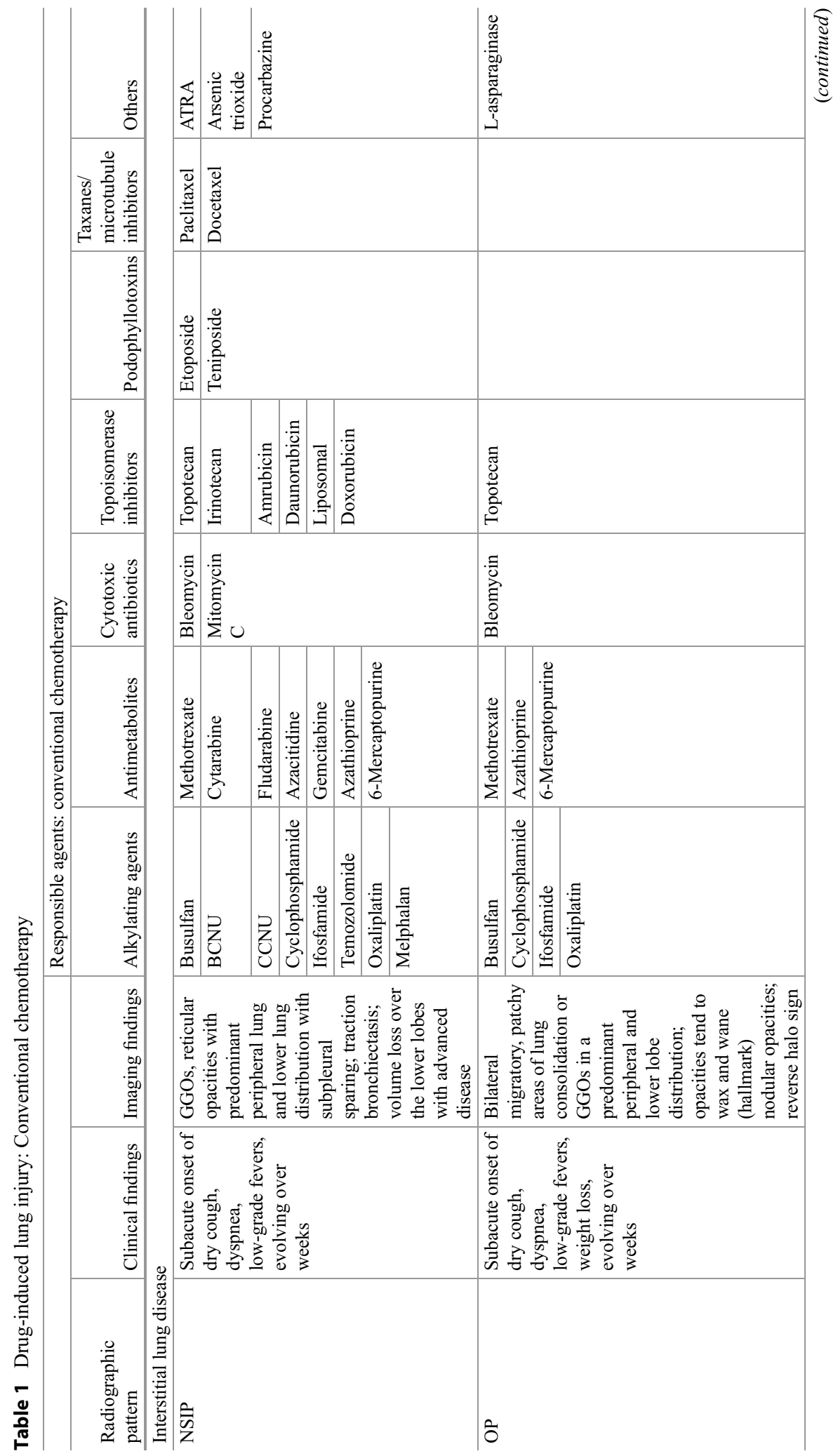




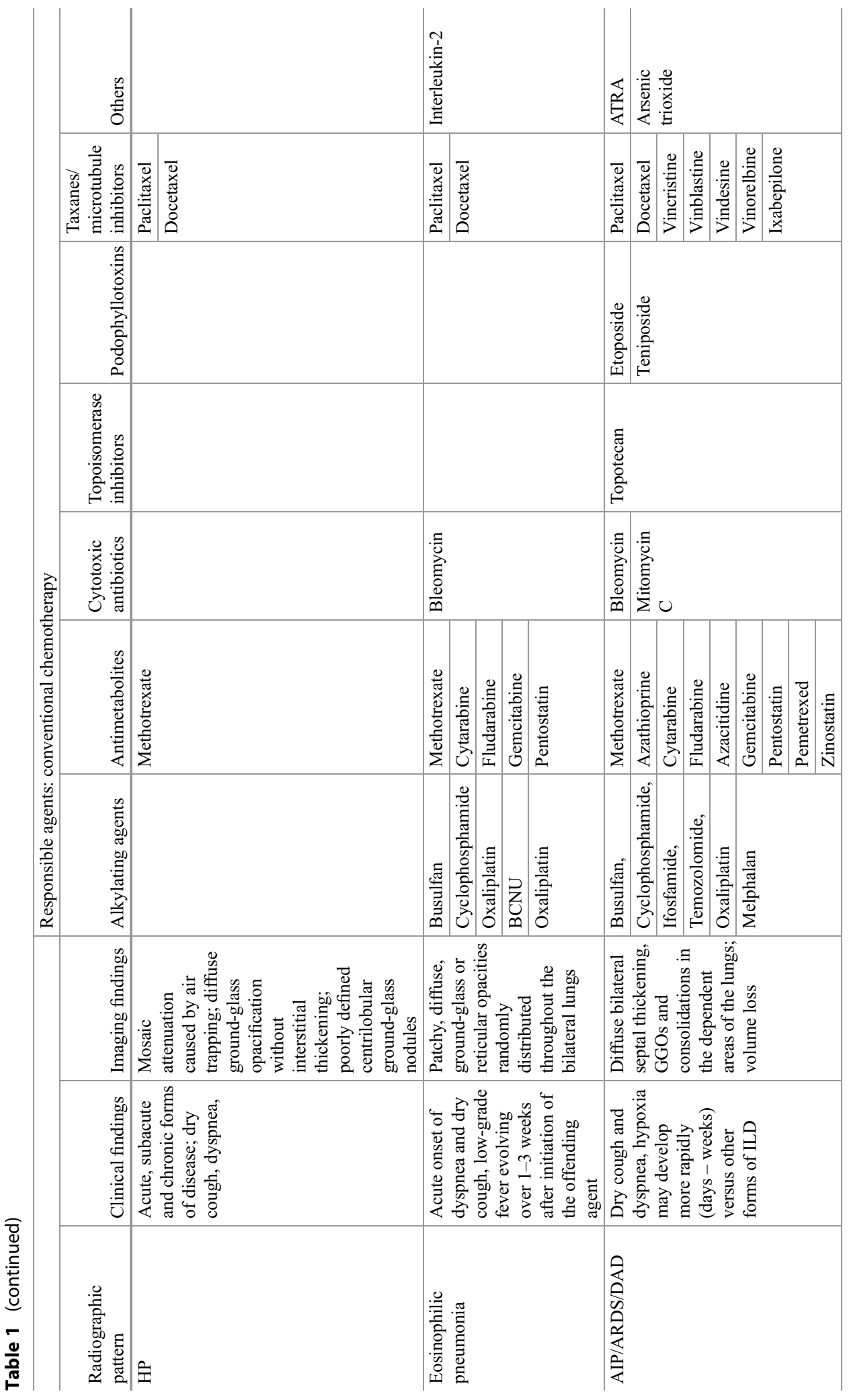




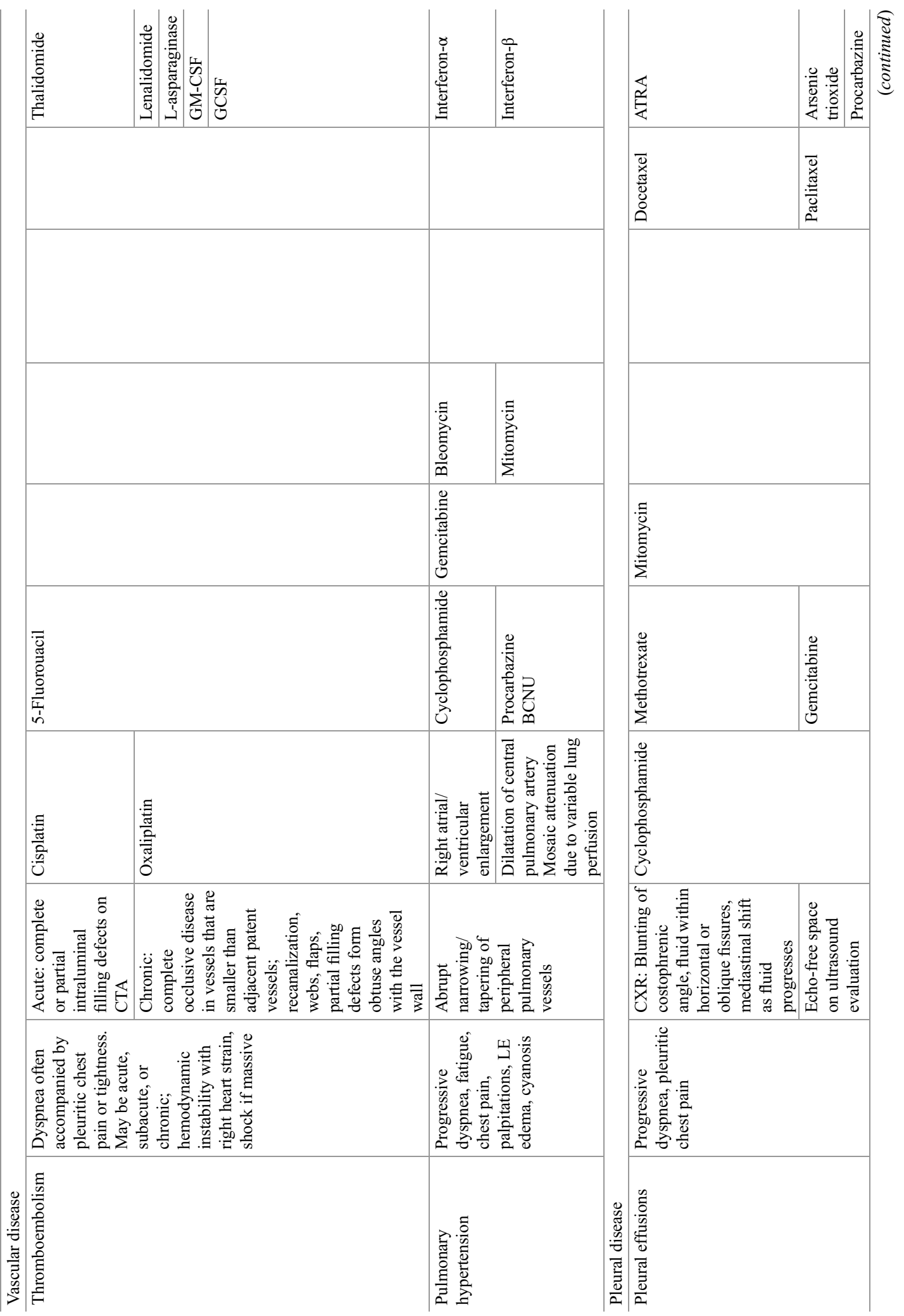




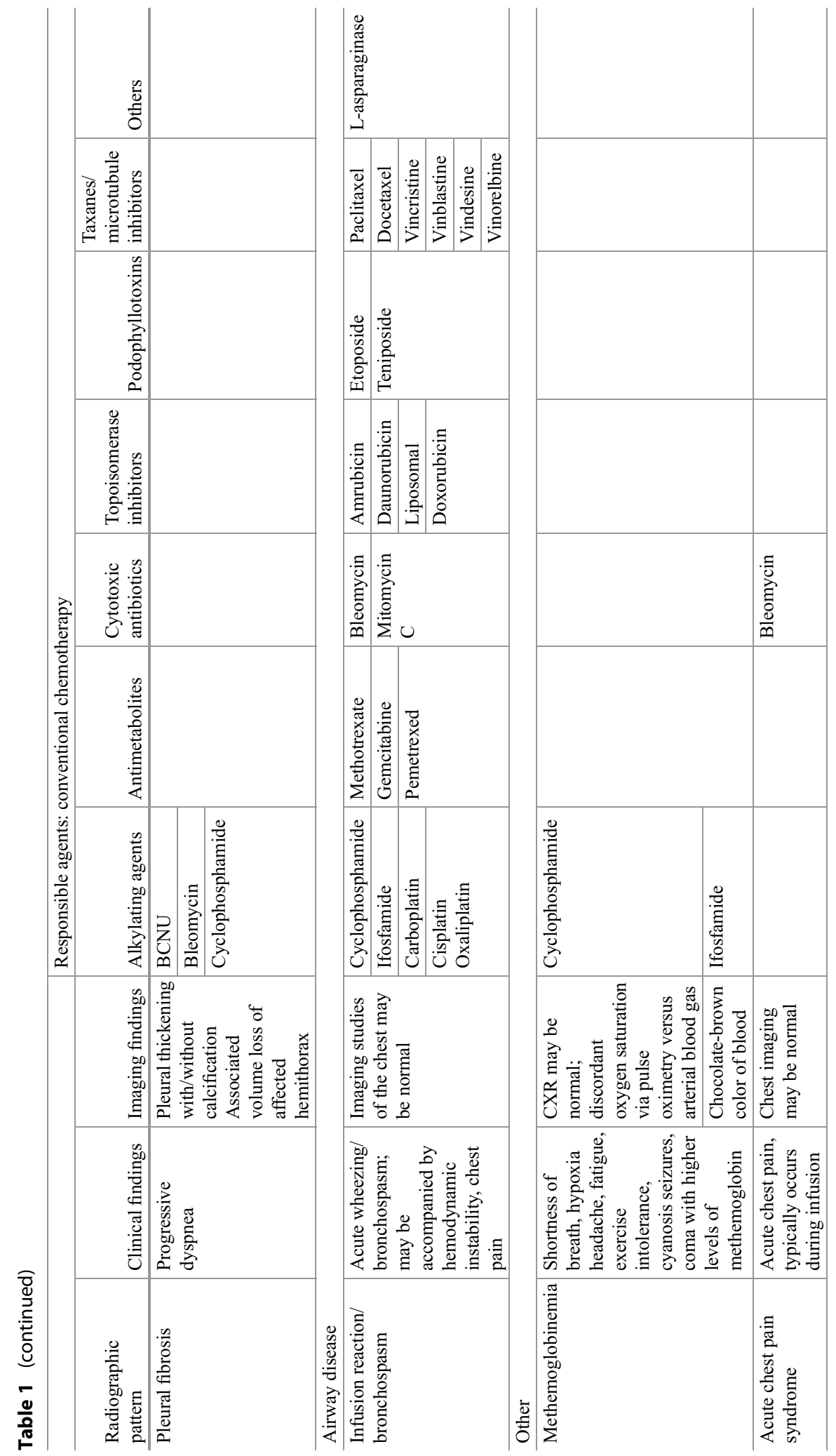




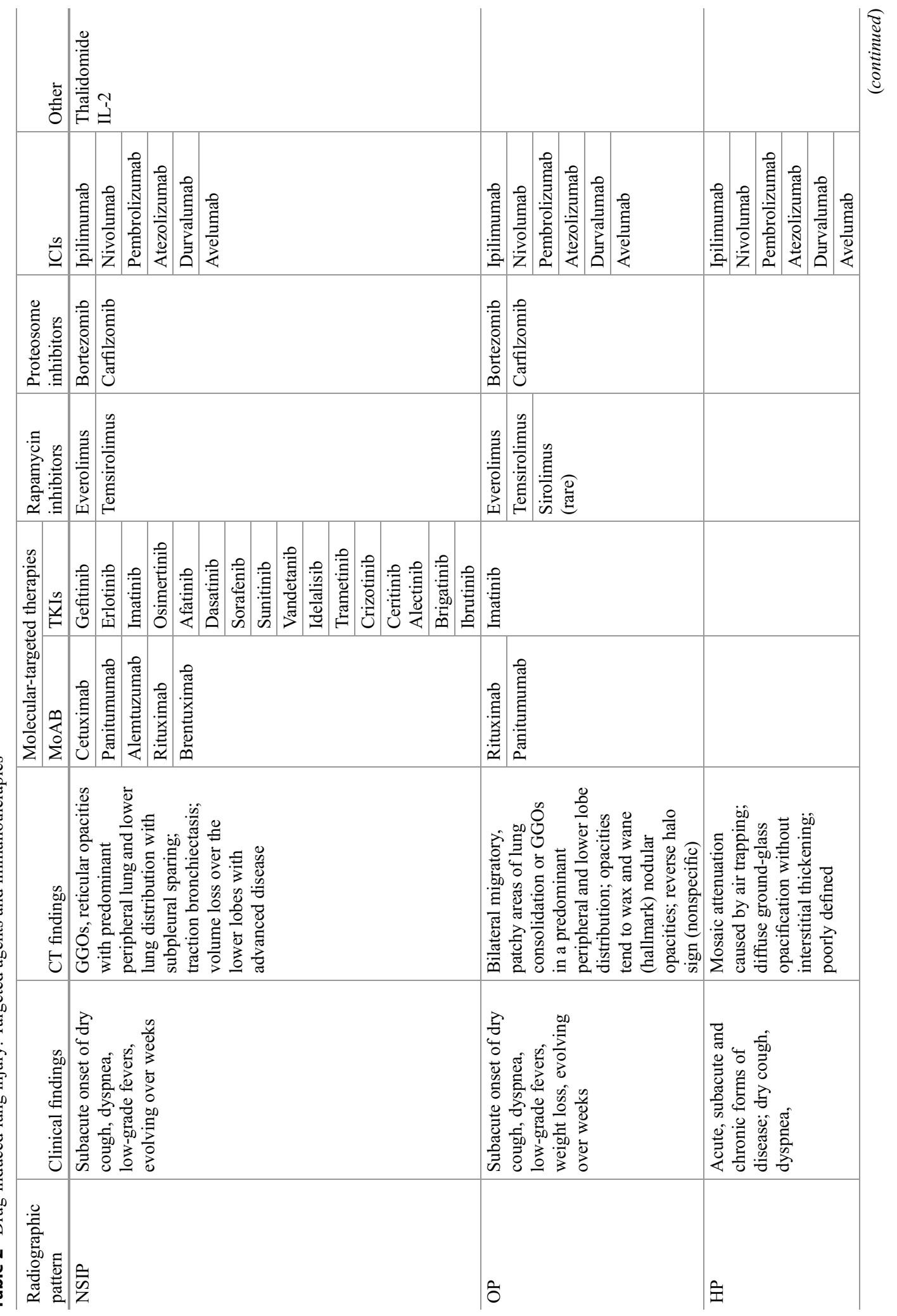




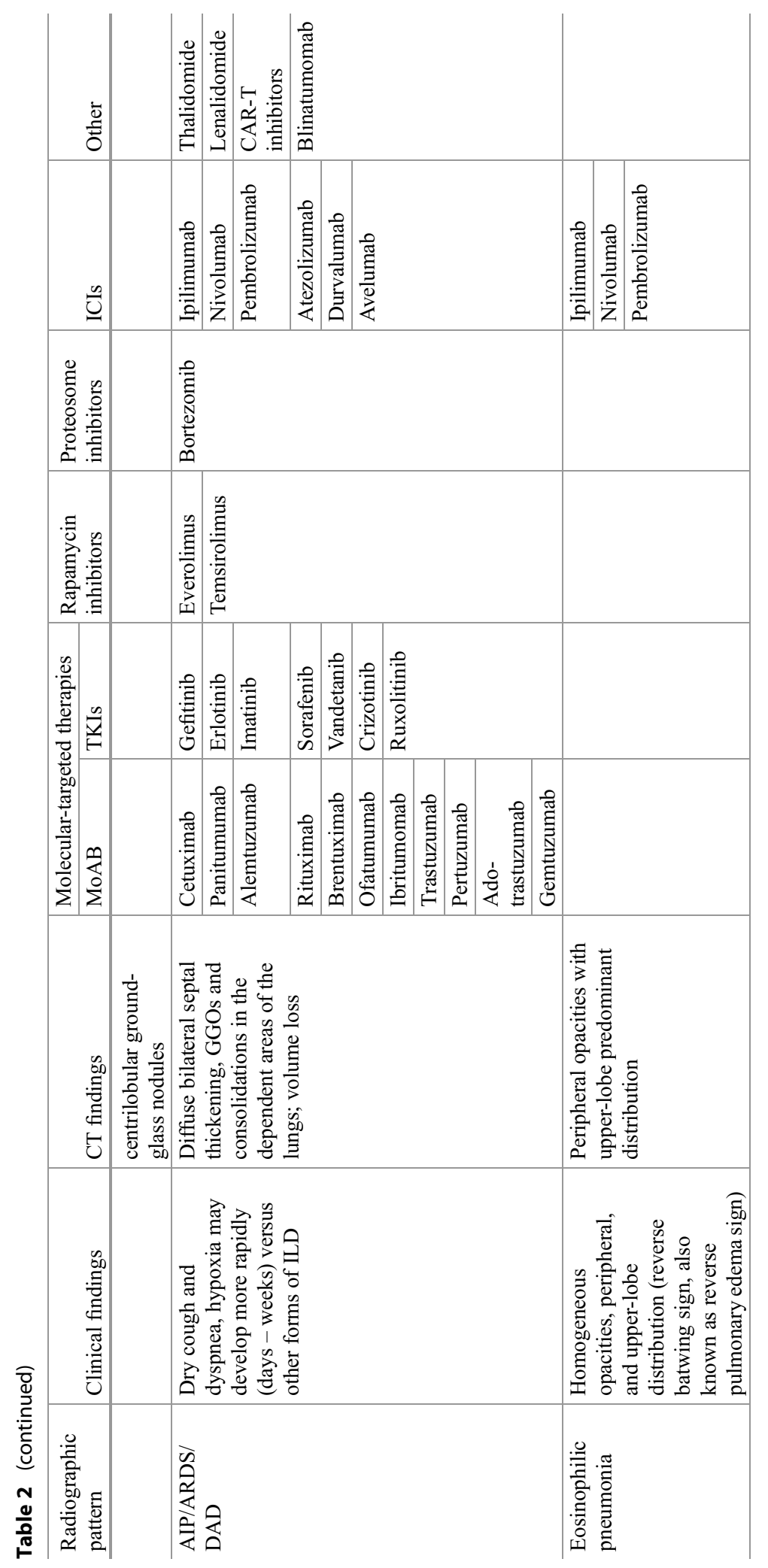




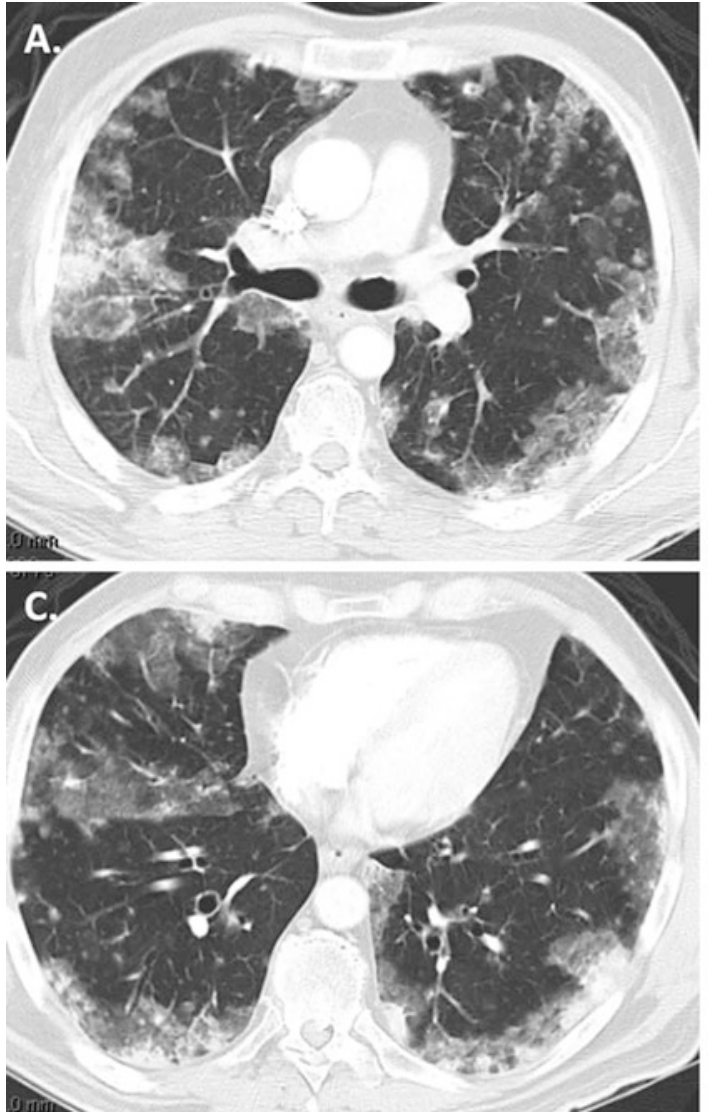

Fig. 1 Gemcitabine-induced lung injury. A 54-year-old man was hospitalized for progressive dyspnea, dry cough, and severe hypoxia 3 weeks after initiation of gemcitabine therapy for pancreatic cancer. The extensive nodular infiltrates with subpleural predominance seen on CT at baseline (a, c) were biopsy-proven to represent metastatic disease. The admitting CT of the chest $(\mathbf{b}, \mathbf{d})$ demonstrated

unilateral or bilateral areas of consolidation that migrate from one area of the lung to another on sequential chest imaging studies, should heighten the suspicion for OP. Other findings include treein-bud branching linear opacities, areas of nodular consolidation, and centrilobular nodules. A lymphocyte-predominant fluid is seen on bronchoscopically obtained sample analysis [35]. PFT abnormalities typically include a mixed obstructive-restrictive pattern in secondary OP. Chemotherapeutic agents that are most commonly implicated in the development of OP include conventional agents (cyclophosphamide, oxaliplatin, methotrexate, bleomycin, busulfan), targeted
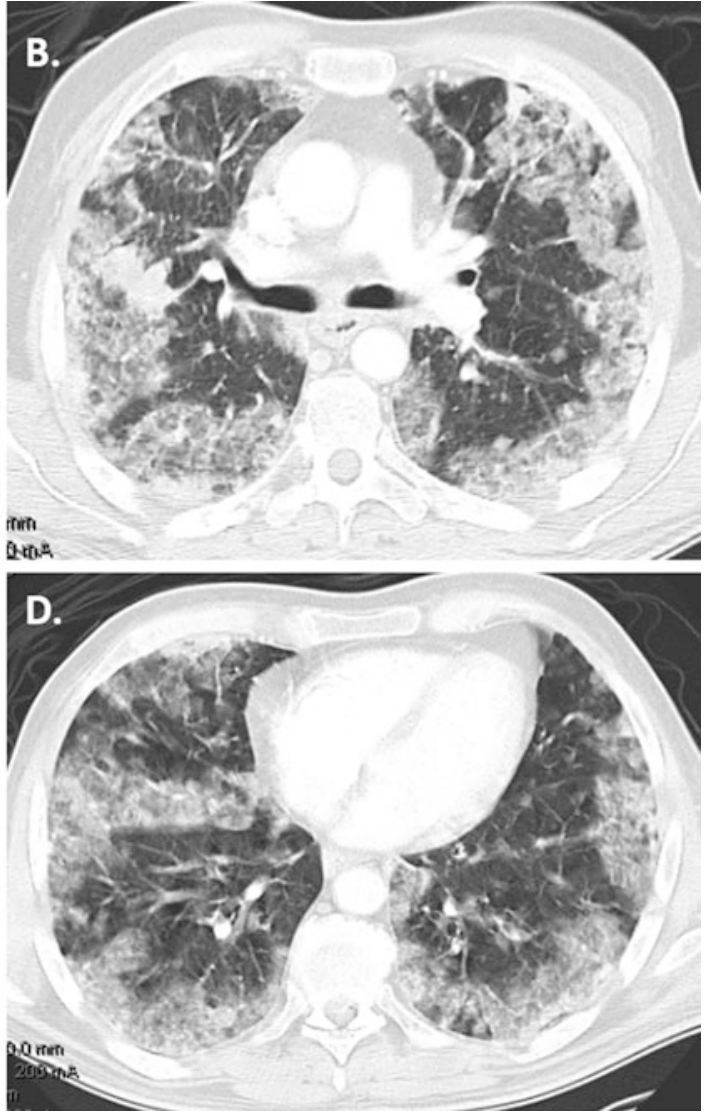

relatively stable nodules with marked increase in the peripheral ground-glass and consolidative opacities bilaterally. Pathologic analysis of lung tissue obtained by transbronchial biopsies confirmed nonspecific interstitial pneumonitis (NSIP) superimposed on known metastatic disease, likely due to gemcitabine therapy

therapies (rituximab, cetuximab, adalimumab, alemtuzumab, everolimus), and immunomodulating agents (ipilimumab, pembrolizumab, nivolumab, atezolizumab, durvalumab). The prognosis of OP is generally favorable. Systemic steroids represent standard therapy, although the precise dose and duration of treatment have not been established. Most reports favor a slow steroid taper (4-6 weeks), to avoid disease relapse. Due to their anti-inflammatory properties, macrolides have also been used with occasional benefit [36].

Hypersensitivity Pneumonitis (HP). This immune-mediated ILD typically develops following repeated exposure to an offending agent. Imaging 
findings suggestive of HP include mosaic attenuation, reflective of air trapping and diffuse groundglass opacification. A predilection for the upper lobes may be seen in chronic forms of the disease. Associated symptoms of fever, dyspnea, dry cough, and rash typically occur over the first 3-4 weeks following drug exposure and may wax and wane without adjustments in therapy. Poorly formed granulomas and BAL lymphocytic alveolitis are common histopathologic findings. Chemotherapeutic agents that most commonly provoke this type of reaction include bleomycin, busulfan, carmustine (BCNU), methotrexate, procarbazine, the taxanes (paclitaxel, docetaxel), and interferon- $\alpha$. Methotrexate is the prototype agent associated with HP, which may develop regardless of route of methotrexate administration (oral, intrathecal, intramuscular, or intravenous). Hypersensitivity reactions have been reported following both Taxol and Taxotere administration, which may arise as a result of the drug or its diluent. Taxol is formulated in a highly allergenic polyoxyethylated castor oil (Cremophor EL) solvent. Up to $10 \%$ of patients develop HP following paclitaxel administration, which is marked by urticaria, bronchospasm, angioedema, and, in extreme cases, hypotension. Paclitaxel-induced HP has been attributed to its Cremophor EL suspension vehicle rather than the agent itself. A hypersensitivity reaction reported following interferon- $\alpha$ has been attributed to the immune-stimulating properties of interferon- $\alpha$, rather than a reaction to the agent itself. Drug withdrawal and steroid therapy typically produce favorable outcomes, with complete resolution of clinical signs and symptoms in early-stage disease. Chronic HP may progress to pulmonary fibrosis with fatal outcomes.

Noncardiogenic Pulmonary Edema (NCPE), Diffuse Alveolar Damage (DAD), and Acute Respiratory Distress Syndrome (ARDS). Druginduced injury to the alveolar-capillary membranes may result in capillary leak and a permeability (noncardiogenic) pulmonary edema. ARDS and its histologic hallmark, DAD, may ensue as the disease progresses. Early histopathologic findings include the accumulation of proteinaceous inflammatory debris, capillary congestion, atelectasis, alveolar edema, and intra-alveolar hemorrhage. This is followed days later by edema of the alveolar septa, thickened alveolar membranes, epithelial cell hyperplasia, and hyaline membrane deposition [37]. Corresponding imaging findings of DAD include septal thickening, atelectasis, and diffuse ground-glass and consolidative opacities, which are most pronounced in the dependent portions of the lungs. DAD may progress to irreversible pulmonary fibrosis. Drug-induced DAD/ARDS may be idiosyncratic, without any relationship to drug dosage or duration of therapy.

Compelling causal drug-related associations arise from nearly all classes of antineoplastic therapies, including cytotoxic antibiotics (bleomycin, mitomycin C); alkylating agents (busulfan, bis-chloroethyl nitrosourea (BCNU), chloroethyl cyclohexyl nitrosourea (CCNU), high-dose cyclophosphamide); antimetabolites (methotrexate, gemcitabine, azathioprine, cytosine-arabinoside, fludarabine); molecularly target agents (gefitinib, erlotinib, cetuximab); antilymphocyte monoclonal antibodies (rituximab, alemtuzumab, ofatumumab); and the rapamycin inhibitors (everolimus, temsirolimus) and the immunomodulating agents (immune checkpoint inhibitors, chimeric antigen receptor $\mathrm{T}$ cells [CAR-T], bispecific $\mathrm{T}$ cell engagers [BiTE], methotrexate). Chemotherapeutic agents such as bleomycin, mitomycin $\mathrm{C}$, busulfan, gentamycin, everolimus, and the nitrosoureas may promote DAD by disrupting the alveolus via apoptosis. Others interfere with repair of the alveolar epithelial barrier (gefitinib, erlotinib, cetuximab) or immune mechanisms (immune checkpoint inhibitors, chimeric antigen receptor T cells [CAR-T], bispecific T cell engagers [BiTE], methotrexate). In many cases, specific mechanism of drug-induced DAD is unknown. Prompt discontinuation of the offending agent is vital, although disease progression may occur despite drug withdrawal.

NCPE leading to ARDS has been described following ruxolitinib, a novel Jakafi one-half inhibitor, as a result of a cytokine rebound reaction. This reaction is mitigated with the preemptive use of corticosteroids and supportive therapy $[38,39]$. Cytokine storm has also been described following all-trans retinoic acid (ATRA) and arsenic trioxide therapies in the treatment of acute promyelocytic leukemia (APL). The 
differentiation syndrome is characterized by potentially fatal NCPE and ARDS and occurs in up to $25 \%$ of APL patients undergoing induction therapy. Unlike many of the lung injury processes, in patients with ATRA and arsenic-related differentiation syndrome, de-escalation of drug dose rather than drug withdrawal, along with systemic steroid therapy, has been associated with successful resolution of toxicity in patients with mild to moderate forms of this syndrome [40, 41].

The onset of ARDS is heralded by acute dyspnea, hypoxia, and bilateral alveolar infiltrates. Reactions may be mild and self-limited, although progression to ARDS with fatal outcomes occasionally occurs. Drug withdrawal, supplemental oxygen, and the judicious use of diuretics usually effect a rapid recovery. With the exception of ATRA- and arsenic-induced NCPE (see above), drug rechallenge with the offending drug often results in recrudescence of symptoms and is not recommended. Aggravating factors that potentiate disease progression to ARDS include multi-agent protocols and the concomitant or sequential use of radiation or oxygen therapy, particularly following therapy with bleomycin or busulfan [42, 43]. Once established, the response of ARDS to drug withdrawal and corticosteroid therapy is variable. Progressive respiratory impairment, leading to respiratory failure and death, has been reported with some agents (busulfan, cyclophosphamide, bleomycin) despite drug withdrawal. Among molecular-targeted therapies, ARDS has been best described following agents that inhibit EGFR (gefitinib, erlotinib, cetuximab), the antilymphocyte monoclonal antibodies (rituximab, alemtuzumab, ofatumumab), and the rapamycin inhibitors (everolimus, temsirolimus). Acute withdrawal of the JAK $1 / 2$ inhibitor, ruxolitinib, has been associated with the development of ARDS as a result of a cytokine rebound reaction. Preemptive use of corticosteroids, along with supportive therapy and a slow taper off this agent, is recommended to mitigate this potential problem $[38,39]$.

Diffuse Alveolar Hemorrhage and Hemoptysis. DAH is typically seen as sequelae of alveolarcapillary membrane injury. Disruption of the alveolar and capillary basement membranes facilitates the entry of red blood cells into the alveoli and represents the histologic change that underlies DAD. Thus, any chemotherapeutic agent that prompts the development of DAD may cause DAH. However, DAH is an uncommon sequela of chemotherapeutic agents, with only a handful of drugs being implicated. Agents such as high-dose cyclophosphamide, cytarabine, gemcitabine, mitomycin, erlotinib, alemtuzumab, and rituximab are most frequently cited as causes of $\mathrm{DAH}$, probably because of the propensity of these agents to trigger DAD. Occasionally, bland alveolar hemorrhage has been described in the absence of DAD following rituximab and alemtuzumab therapy [38, 44]. Affected patients may present with acute hypoxemic respiratory distress. Patients often present with abrupt dyspnea and cough which may progress to acute hypoxemic respiratory failure. Hemoptysis may be minimal or absent in approximately $25-30 \%$ of patients, despite massive bleeds $[45,46]$. The diagnosis of DAH is confirmed by progressively bloody aliquots of bronchoalveolar lavage (BAL) fluid. Cytologic evidence of increased hemosiderin-laden macrophages $(>20 \%)$ is also supportive. CT findings of diffuse, bilateral ground-glass opacities or consolidative changes are typical. Early recognition and discontinuation of the offending agent are crucial, as prompt diagnosis and treatment improve survival. Corticosteroids and immunosuppressive agents are often used, although their efficacy in this setting has not been formally evaluated.

Massive and sometimes fatal bleeding has been reported during bevacizumab therapy for treatment of central airway tumors [47]. The inhibition of VEGF is the putative mechanism, which may cause destruction of normal lung tissue and subsequent hemoptysis. Hemoptysis following VEGF inhibitor therapies has been reported more often in association with lung cancers of squamous cell histology, which is likely due to the central location of these tumors [48]. Treatment requires discontinuation of the drug and stabilization of the patient, preferably in an intensive care unit setting. Management of massive hemoptysis is beyond the scope of this chapter but typically includes early bronchoscopy performed with either rigid or flexible endoscope 
(or both), endovascular embolization, and, in selected cases, surgery, with goals of controlling the bleeding and prevention of aspiration.

Eosinophilic Pneumonia. Eosinophilic pneumonia is characterized by an inappropriate increase in the number of eosinophils and macrophages within alveoli, causing the alveolar septa to become engorged. Progressive dyspnea, dry cough, and occasionally fever are nonspecific clinical correlates. Elevated peripheral eosinophilia and elevated IgE levels and nonsegmental homogeneous opacities with peripheral and upper-lobe distribution (reverse batwing sign, also known as reverse pulmonary edema sign) are important clinical clues. Causative agents include the taxanes, methotrexate, gemcitabine, fludarabine, and interferon- $\alpha$. Drug-related EP may resolve with cessation of therapy and initiation of systemic steroids.

Pleural Effusions. Drug-induced pleural effusions may occur as an isolated toxicity to the pleura (following methotrexate, dasatinib, bosutinib, docetaxel, ATRA, and granulocyte colony-stimulating factor (GCSF) administration) or as a manifestation of a generalized pleuroparenchymal abnormality $[49,50]$. These small- to moderate-sized effusions are typically exudative and lymphocyte predominant and may be unilateral or bilateral. Withdrawal of the offending agent may result in spontaneous resolution in some cases.

Pulmonary Vascular Disorders (PVD). The development of thromboembolic disease, pulmonary hypertension, and pulmonary veno-occlusive disease has been described following conventional chemotherapeutic, molecularly targeted, and immunomodulating agents. Increased rates of venous thromboembolism (pulmonary embolism and deep venous thrombosis) have been reported with the ALK inhibitor crizotinib, Bcr-Abl inhibitor ponatinib, and VEGF inhibitors bevacizumab, sunitinib, sorafenib, and pazopanib [51, 52]. In addition, the angiogenesis inhibitors (thalidomide, revlimid, pomalidomide) in combination with steroids, doxorubicin, or BCNU are associated with $14-43 \%$ increased risk of thromboembolic events. Other agents, including hormonal therapies, growth factors, and erythropoietic agents, contribute to cancer-associated venous thromboembolism. The development of pulmonary arterial hypertension $(\mathrm{PAH})$ has been associated with several drugs, including bleomycin, busulfan, BCNU, interferon, and dasatinib. Severe $\mathrm{PAH}$ following dasatinib, a multi-kinase Bcr-Abl tyrosine kinase inhibitor (TKI), is well described. Once dasatinibassociated PAH develops, drug withdrawal without rechallenge is recommended. There are no reports of PAH following exposure to the more selective Bcr-Abl targeted TKIs (imatinib and nilotinib), which may be safely used in dasatinib-induced $\mathrm{PAH}[16,53-55]$. Bleomycin and BCNU have also been implicated in the development of PVOD, an irreversible and often fatal form of pulmonary hypertension that is characterized by fibrous obliteration of pulmonary venules.

Drug-Induced Airway Disease. Virtually all chemotherapeutic and targeted agents may trigger an infusion reaction (IR), a sometimes lifethreatening acute reaction that may be associated with dry cough, dyspnea, wheezing, chest pain, and hypoxia. IRs may manifest as IgE-mediated, type 1 hypersensitivity reactions (carboplatin, oxaliplatin, and L-asparaginase) or as anaphylactoid reactions, mediated by cytokine release. The latter reaction is often seen following the administration of several monoclonal antibodies (mAbs). IRs may be triggered by the drug itself or in response to the vehicle in which the drug is formulated. This is particularly true of the taxane class of drugs. For example, paclitaxel is formulated in Cremophor EL, a highly allergenic polyoxyethylated castor oil solvent. Docetaxel is formulated in polysorbate 80 . Both vehicles may induce mast cell/basophil activation and subsequent hypersensitivity reaction. Other drugs that are formulated in Cremophor EL (cyclosporine, teniposide, ixabepilone) or polysorbate 80 (etoposide) may trigger similar reactions and should be avoided in patients with a history of IRs following taxane administration $[56,57]$. Histamine receptor antagonists and steroids are recommended as standard prophylaxis prior to taxane administration, which has reduced the incidence of taxaneinduced bronchospasm from $30 \%$ to $2 \%$ [58]. IRs may occur within minutes to several hours following drug exposure. Close monitoring during and immediately following drug infusion is critical, as 
breakthrough IRs may occur despite prophylaxis. Although vinca alkaloids are rarely associated with lung toxicity, severe bronchospasm has been described when these agents are given with concurrent or sequential administration of mitomycin therapy [59].

Infections. Lung infections are frequent sequelae of aggressive immunosuppressive regimens. The conventional chemotherapeutic agents as well as molecular-targeted therapies may promote recalcitrant and sometimes life-threatening opportunistic pneumonias [60-77]. Increased infection risk in this setting is primarily due to the development of drug-related neutropenia, lymphopenia, and/or impairment of $\mathrm{T}$ cell and $\mathrm{B}$ cell function. Reactivation of tuberculosis has been reported following anti-PD-1 therapies [78]. Agents that are more frequently linked to an increased infection risk are listed in Table 3.

Methemoglobinemia. Methemoglobinemia is a rare but potentially fatal blood disorder in which the iron of heme is oxidized in excess to the ferric $(\mathrm{Fe}+++)$ state. Ferric hemes of methemoglobin exhibit an impaired affinity for oxygen, while the remaining heme sites within the same tetrameric hemoglobin that are in ferrous state demonstrate an increased affinity for oxygen. This imbalance results in poor oxygen delivery, tissue hypoxia. As methemoglobin levels increase, clinical symptoms of shortness of breath, cyanosis, fatigue, exercise intolerance, dizziness, shock, neurologic disturbances (headache, mental status changes, seizures, coma), and death may ensue. Severe symptoms may occur at lower levels of methemoglobin in the setting of preexisting conditions, such as anemia, coexistent glucose-6phosphate dehydrogenase (G6PD) deficiency, and chronic lung or heart disease. Exposure to dapsone, topical anesthetic agents, and other oxidant drugs are the most common precipitating agents associated with acquired methemoglobinemia. Two chemotherapeutic agents, cyclophosphamide, and a structurally similar compound, ifosfamide, are important causes of methemoglobinemia. This diagnosis should be considered in the differential of patients who develop acute shortness of breath, cyanosis, respiratory depression, or altered sensorium during treatment with one of these agents [79]. Hypoxia that is refractory to supplemental oxygen, abnormal chocolate coloration of the blood, and clinical cyanosis in the presence of normal $\mathrm{PaO} 2$ are important diagnostic clues. Drug withdrawal is the mainstay of therapy. Depending on the clinical presentation, blood transfusions, methylene blue, and intensive care monitoring for stabilization of the airway and hemodynamics should be considered.

\section{Lung Injury Associated with Cancer Immunotherapies}

\section{Immune Checkpoint Blocking Agents}

A key responsibility of the host immune system is to target and destroy cancer cells. This process is mediated via a series of tightly regulated co-stimulatory and co-inhibitory immunomodulatory signals that result in a dynamic state of equilibrium between immune attack and immune tolerance. Immunerelated adverse events (IrAEs) may involve virtually every major organ system, including the lungs. Lung involvement is infrequent; however, pneumonitis associated with immune checkpoint inhibitors (ICIs) represents one of the most severe and potentially fatal forms of IrAEs. The incidence of ICI-related pneumonitis ranges from $5 \%$ to $11 \%$, with the most frequent and severe events occurring following combination strategies using concurrent or sequential anti-CTLA-4/PD-1 regimens [80-84]. Nonspecific symptoms of new or worsening dry cough, fatigue, and shortness of breath typically occur within the first 3-6 months of initiation of therapy. Fever and chest pain have also rarely been described. Tachycardia and hypoxia are ominous signs which may presage advance disease. Bronchoscopy and lung biopsy can be helpful in excluding competing diagnoses, such as lymphangitic carcinomatosis, pneumonia, pulmonary edema, alveolar hemorrhage, or preexisting lung disease. A lymphocyte-predominant bronchoalveolar lavage (BAL) fluid is common. 
Table 3 Chemotherapeutic agents and infection risk

\begin{tabular}{|c|c|c|c|}
\hline Agent class & Infection risk & Mechanism & Refs \\
\hline \multicolumn{4}{|c|}{ Conventional chemotherapy } \\
\hline $\begin{array}{l}\text { Alkylating agents } \\
\text { Chlorambucil } \\
\text { Cyclophosphamide } \\
\text { Bendamustine }\end{array}$ & $\begin{array}{l}\text { Bacterial } \\
\text { Fungal } \\
\text { HBV reactivation (bendaustine, } \\
\text { chlorambucil) }\end{array}$ & $\begin{array}{l}\text { Neutropenia } \\
\text { Lymphopenia (T cell dysfunction) } \\
\text { Lymphopenia (B and T cell } \\
\text { dysfunction, bendamustine, cladribine, } \\
\text { pentostatin) }\end{array}$ & {$[113]$} \\
\hline $\begin{array}{l}\text { Purine/pyrimidine } \\
\text { analogues } \\
\text { Fludarabine } \\
\text { Cladribine } \\
\text { Pentostatin } \\
\text { 6-Mercaptopurine } \\
\text { Cytosine } \\
\text { arabinoside } \\
\text { Azathioprine }\end{array}$ & $\begin{array}{l}\text { Listeria, PJP, nocardia } \\
\text { Mycobacterial infections } \\
\text { Opportunistic fungal infections } \\
\text { Viral (CMV, VZV, HSV) }\end{array}$ & $\begin{array}{l}\text { Lymphopenia (T cell dysfunction - } \\
\text { fludarabine) } \\
\text { Lymphopenia (B and T cell dysfunction } \\
\text { - cladribine, pentostatin) }\end{array}$ & [114] \\
\hline \multicolumn{4}{|l|}{ Targeted agents } \\
\hline $\begin{array}{l}\text { Bruton tyrosine } \\
\text { kinase } \\
\text { Inhibitors } \\
\text { Ibrutinib } \\
\text { Acalabrutinib }\end{array}$ & $\begin{array}{l}\text { Opportunistic fungi (Aspergillus, } \\
\text { Cryptococcus, PJP, Fusarium) } \\
\text { HBV reactivation }\end{array}$ & $\begin{array}{l}\text { Lymphopenia (B-cell dysfunction, ? T } \\
\text { cell dysfunction) }\end{array}$ & [115] \\
\hline $\begin{array}{l}\text { Proteasome } \\
\text { inhibitors } \\
\text { Carfilzomib } \\
\text { Bortezomib }\end{array}$ & Viruses (VZV) & T cell dysfunction & {$[116]$} \\
\hline $\begin{array}{l}\text { Anti-CD20-target } \\
\text { Rituximab } \\
\text { Obinutuzumab } \\
\text { Ofatumumab }\end{array}$ & $\begin{array}{l}\text { Viruses (herpesvirus-CMV, HSV, VZV, } \\
\text { enterovirus, JC virus); HBV reactivation }\end{array}$ & $\begin{array}{l}\text { Lymphopenia (B cell dysfunction) } \\
\text { Neutropenia (obinutuzumab) }\end{array}$ & {$[64]$} \\
\hline $\begin{array}{l}\text { Anti-CD-52 target } \\
\text { Alemtuzumab }\end{array}$ & $\begin{array}{l}\text { Viruses (herpesviruses - CMV, HSV, } \\
\text { VZV) } \\
\text { Fungal (PJP, Aspergillus, Zygomycetes, } \\
\text { Candida) }\end{array}$ & $\begin{array}{l}\text { Lymphopenia (B, T and NK cell } \\
\text { dysfunction) }\end{array}$ & {$[65]$} \\
\hline $\begin{array}{l}\text { mTOR inhibitors } \\
\text { Temsirolimus } \\
\text { Everolimus } \\
\text { Sirolimus }\end{array}$ & $\begin{array}{l}\text { Bacterial } \\
\text { Fungal }\end{array}$ & $\mathrm{B}$ and $\mathrm{T}$ cell dysfunction & {$[66]$} \\
\hline $\begin{array}{l}\text { P13K inhibitors } \\
\text { Idelalisib } \\
\text { Brigatinib }\end{array}$ & $\begin{array}{l}\text { Bacterial } \\
\text { Fungal (PJP, Aspergillus) }\end{array}$ & $\begin{array}{l}\text { Neutropenia } \\
\text { Lymphopenia (B and T cell } \\
\text { dysfunction) }\end{array}$ & {$[69]$} \\
\hline $\begin{array}{l}\text { BCL2 inhibitors } \\
\text { Venetoclax }\end{array}$ & $\begin{array}{l}\text { Bacteria } \\
\text { Viruses (enterovirus) }\end{array}$ & $\begin{array}{l}\text { Neutropenia } \\
\text { Lymphopenia (B and T cell } \\
\text { dysfunction) }\end{array}$ & {$[70]$} \\
\hline $\begin{array}{l}\text { Jak-1 inhibitors } \\
\text { Ruxolitinib }\end{array}$ & $\begin{array}{l}\text { Fungal (PJP, Cryptococcus) } \\
\text { Mycobacteria (MTB); HBV reactivation }\end{array}$ & T cell dysfunction & [71-73] \\
\hline $\begin{array}{l}\text { Immunomodulators } \\
\text { Thalidomide } \\
\text { Lenalidomide }\end{array}$ & $\begin{array}{l}\text { Viral } \\
\text { Fungal }\end{array}$ & $\begin{array}{l}\text { Neutropenia } \\
\text { Lymphopenia (B and T cell } \\
\text { dysfunction) }\end{array}$ & {$[75]$} \\
\hline $\begin{array}{l}\text { Anti-cytokines } \\
\text { IFN- } \alpha \\
\text { TNF- } \alpha \text { (infliximab) }\end{array}$ & $\begin{array}{l}\text { Fungal (PJP, Cryptococcus) } \\
\text { Mycobacteria (MTB) } \\
\text { HBV reactivation }\end{array}$ & T cell dysfunction & {$[77]$} \\
\hline \multicolumn{4}{|c|}{ Immune checkpoint inhibitors } \\
\hline $\begin{array}{l}\text { Anti-PD-1 } \\
\text { therapies }\end{array}$ & TB reactivation & Anti-PD-1 activity & {$[78]$} \\
\hline
\end{tabular}


Occasionally, peripheral and BAL eosinophilia, suggestive of eosinophilic pneumonia, may be seen. Histopathologic findings of a cellular interstitial pneumonitis, organizing pneumonia, or diffuse alveolar damage may progress to traction bronchiectasis with pulmonary fibrosis (Fig. 2). Groundglass and reticular changes with subpleural and basilar predominance and patchy, consolidative changes on chest imaging studies are also nonspecific. These findings do not distinguish ICI-related IP from other causes. A concurrent or sequential history of extrapulmonary IrAEs involving the skin, gut, thyroid, or other organs may occur in more than $50 \%$ of patients and should raise the index of suspicion [82, 84-88]. Organizing pneumonia and cellular interstitial pneumonitis represent the most frequent histopathologic findings which may progress to traction bronchiectasis with pulmonary fibrosis with advanced stages of disease. Other ICI-mediated respiratory events include bronchitis, bronchiolitis, pleural disease, sarcoid-like reactions, pulmonary granulomatosis, and pseudoprogression of the underlying malignancy [89-93].

The Common Terminology Criteria for Adverse Events (CTCAE) has been widely utilized to establish guidelines for the management of IrAEs. This scoring system uses organ-specific parameters to stratify the severity of therapyrelated organ toxicities. Accordingly, symptom scoring ranges from asymptomatic (grade 1) to

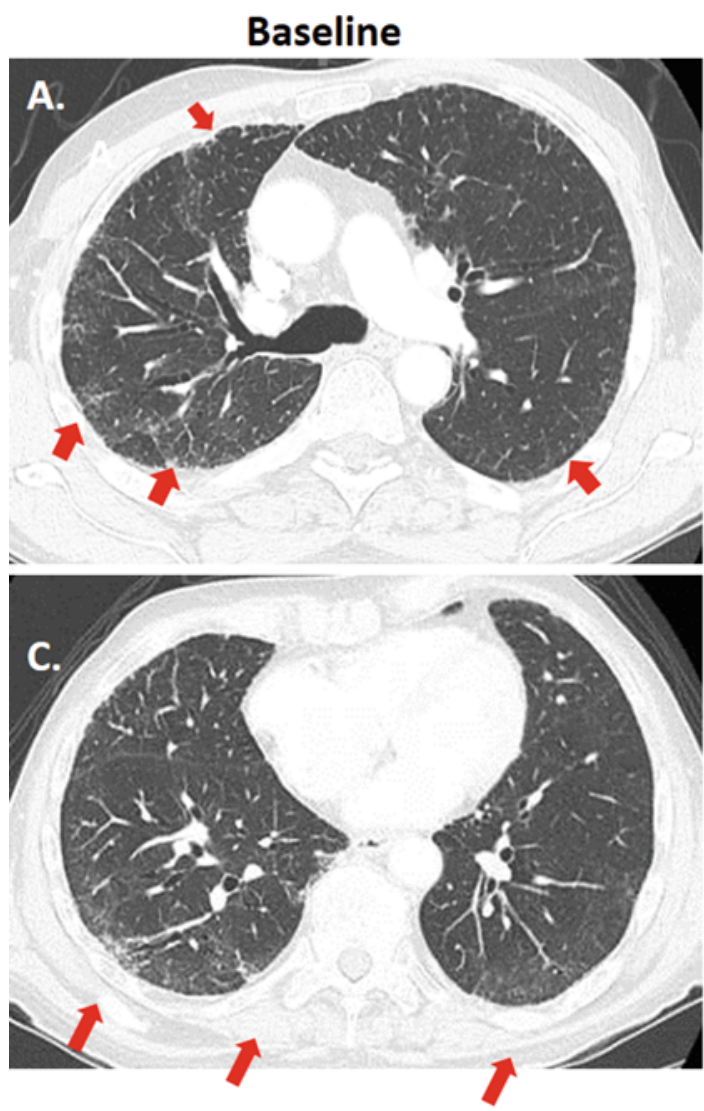

Fig. 2 Ipilimumab-induced lung injury. A 78-year-old man treated with combined ipilimumab monotherapy for melanoma presented 5 days after cycle 1 of therapy with dyspnea and dry cough. Asymptomatic idiopathic pulmonary fibrosis was coincidentally found on CT imaging studies 5 years prior to the cancer diagnosis. Subtle,

\section{Ipilimumab, (course 1, day 5)}
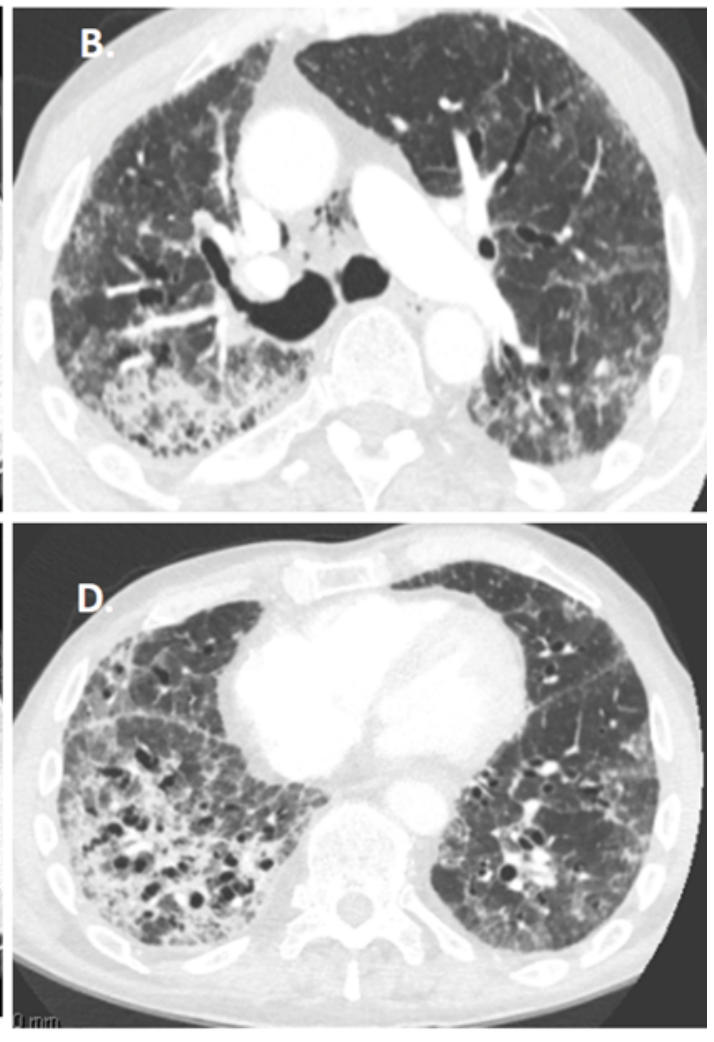

subpleural reticular changes at baseline (arrows, a, c) are consistent with the patient's known history of pulmonary fibrosis. Extensive superimposed areas of bilateral groundglass densities are seen on the admitting CT $(\mathbf{b}, \mathbf{d})$, which corresponded to organizing pneumonia on lung biopsies, felt to be related to ipilimumab 
Table 4 CTCAE scoring system and consensus guidelines in the management of lung injury associated with immune checkpoint inhibitor therapies

\begin{tabular}{l|l|l}
\hline $\begin{array}{l}\text { Pneumonitis } \\
\text { grade }\end{array}$ & Clinical symptoms & Treatment recommendations \\
\hline 1 & Asymptomatic & $\begin{array}{l}\text { Withhold therapy; close clinical and diagnostic } \\
\text { follow-up to determine timing and feasibility of } \\
\text { resumption of therapy; if evidence of disease } \\
\text { progression, treat as higher-grade pneumonitis }\end{array}$ \\
\hline 2 & $\begin{array}{l}\text { Mild symptoms of dyspnea with moderate } \\
\text { exertion; minimal interference with activities } \\
\text { of daily living }\end{array}$ & $\begin{array}{l}\text { Withhold therapy; initiate corticosteroid therapy in } \\
\text { select cases; close clinical and diagnostic follow-up } \\
\text { to determine timing and feasibility of resumption of } \\
\text { therapy; if evidence of disease progression, treat as } \\
\text { higher-grade pneumonitis }\end{array}$ \\
\hline 3 & $\begin{array}{l}\text { Dyspnea at rest; dyspnea limits activities of } \\
\text { daily living and self-care }\end{array}$ & $\begin{array}{l}\text { Discontinue therapy; hospitalize and initiate } \\
\text { corticosteroid therapy; if evidence of disease } \\
\text { progression, treat as higher-grade pneumonitis }\end{array}$ \\
\hline 4 & $\begin{array}{l}\text { Severe, life-threatening symptoms, } \\
\text { respiratory compromise }\end{array}$ & $\begin{array}{l}\text { Permanent discontinuation of therapy; hospitalize } \\
\text { with higher-level (ICU) care; initiate corticosteroid } \\
\text { therapy }\end{array}$ \\
\hline
\end{tabular}

severe (grade 4) pneumonitis (Table 4). For grade 1 pneumonitis, withholding the drug with close outpatient monitoring is recommended. Drug rechallenge among this group of patients may be considered on a case-by-case basis, if repeat imaging studies, performed 2-4 weeks after withholding the drug, demonstrate resolution of infiltrates. Current consensus favors inpatient management with initiation of systemic corticosteroid therapy among patients with grade 3-4 pneumonitis and patients with grade 2 pneumonitis who demonstrate progression of toxicity despite drug cessation [7, 87, 94-96]. Early grade (1-2) pneumonitis may rapidly progress to respiratory failure and death in $1-2 \%$ of patients. Thus, close monitoring of patients with all grades of pneumonitis is recommended.

\section{Genetically Engineered Immunotherapies}

Recent success in the use of genetically engineered T cells in the treatment of hematologic malignancies has inspired tremendous interest in this area. This process involves ex vivo modification of the naïve $\mathrm{T}$ cell to express a unique highaffinity $T$ cell receptor (TCR) or a chimeric antigen receptor (CAR). The modified $T$ cells are expanded and infused into the recipient through a process called adoptive cell transfer. The two major classes of engineered $\mathrm{T}$ cell therapies, known as chimeric antigen receptor $\mathrm{T}$ cells (CAR-T) and bispecific T cell engagers (BiTEs), have advantages over conventional therapies in their ability to target unique antigens on tumor cells with a precision that standard chemotherapy and radiation cannot, resulting in cytologic killing of specific antigen-positive tumor targets. In addition, these agents have the capacity to promote large-scale T cell expansion [96-101]. BiTEs are antibody-derived molecules with dual antigen specificity, allowing them to simultaneously bind unique antigens on the T cell and the tumor cell, thereby facilitating cytotoxic cell-to-cell interactions and tumor cell killing.

Engineered T cells are "living drugs" which may induce organ toxicity well after discontinuation of the agent. The most prominent toxicity of both CAR-T and BiTE therapies is cytokine release syndrome (CRS), a systemic inflammatory response that is thought to be caused by rapid $\mathrm{T}$ cell proliferation with the toxic release of pro-inflammatory cytokines, such as IFN-g, TNF-a, and IL-6 following therapy. These cytokines may promote damage to the endothelium and other organs, resulting in microvascular leakage, and potentially fatal organ system damage to the heart, liver, lung, and kidneys [102]. Patients may present with rapid onset of high fever, rigors, 

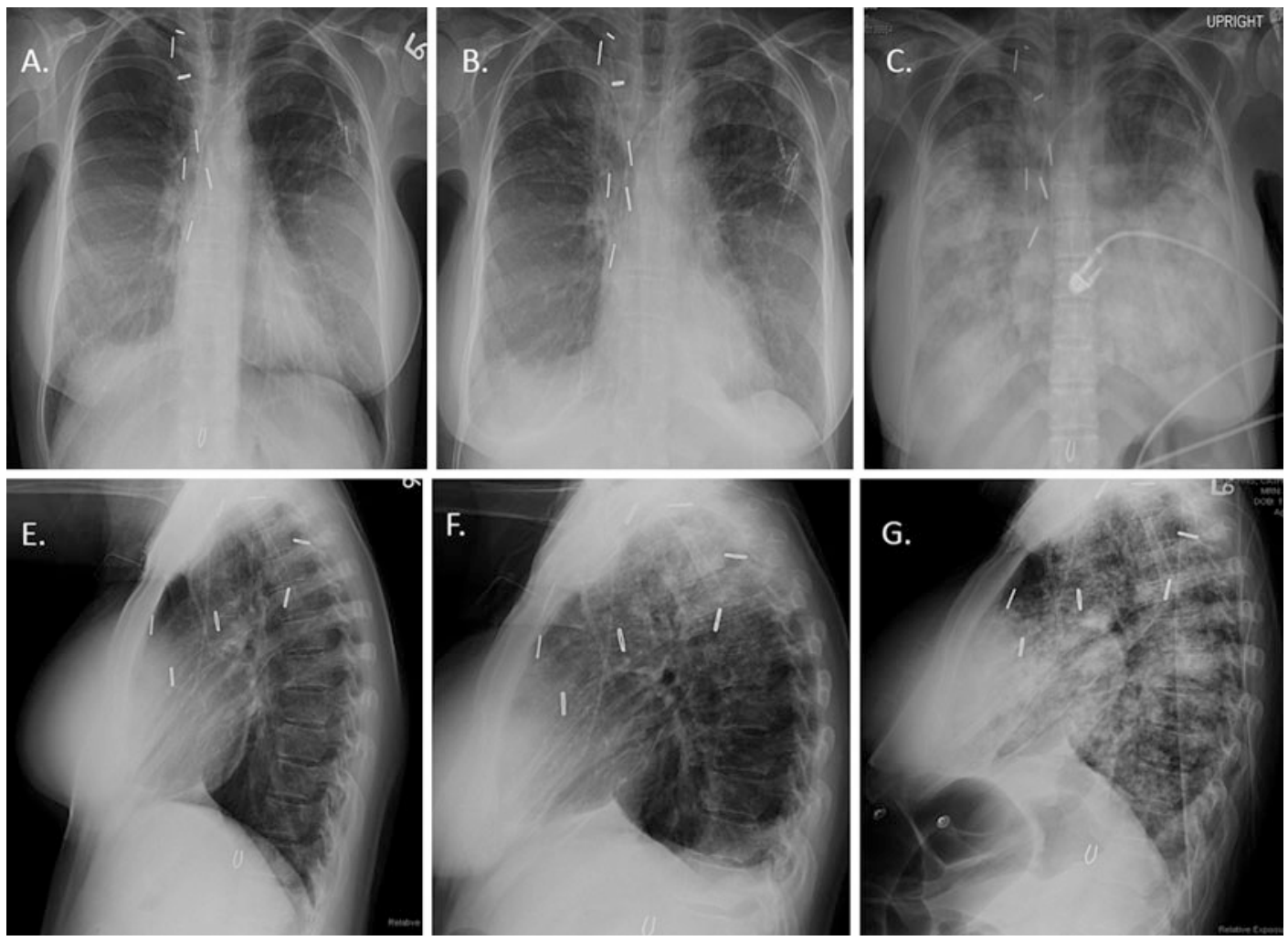

Fig. 3 Cytokine release syndrome associated with blinatumomab therapy. A 47-year-old woman developed acute, severe dyspnea, dry cough, and low-grade fever $7 \mathrm{~h}$ following infusion of blinatumomab for refractory ALL. Over the ensuing $24 \mathrm{~h}$, the patient required vasopressor support and was intubated and placed on mechanical

chills, myalgias, dyspnea, hypoxia, and hemodynamic instability $4-16 \mathrm{~h}$ following drug infusion (Fig. 3). Supportive care, including fluid resuscitation, vasopressor support, supplemental oxygen, and intubation, may be required for patients with severe symptoms. Systemic corticosteroids and treatment with IL-6 receptor-directed therapy with tocilizumab are also used to suppress the intense inflammatory response [96, 103, 104].

\section{Radiation-Induced Lung Injury}

Clinically significant radiation-induced lung injury (RILI) is the most common dose-limiting complication of thoracic radiation therapy (RT), occurring in $5-20 \%$ of patients. Recent advances ventilation for hypoxemic respiratory failure. Bronchoscopically obtained distal airway samples were culture negative and without evidence of malignant cells. The patient was started on high-dose steroids and tocilizumab but succumbed to refractory hypoxemia and hypotension, felt to be due to cytokine release syndrome

in radiation techniques and delivery systems, such as proton therapy, three-dimensional conformal RT (CRT), intensity-modulated RT (IMRT), and stereotactic body RT (SBRT), purport lower lung injury rates while delivering higher target doses of radiation to the lung. Factors associated with radiation delivery (total radiation dose, dose per fraction, volume of irradiated lung, and beam characteristics and arrangements) and clinical factors (preexisting lung disease, underlying poor pulmonary reserve, prior radiotherapy, multimodality regiments, rapid steroid withdrawal) all potentiate the appearance and severity of radiation pneumotoxicity. Radiographically apparent lung injury is common with total doses of radiation that exceed 40 Gy and is rare at doses below 20 Gy $[105,106]$. Hyperfractionated 
radiation doses delivered to the smallest lung volume are recommended.

\section{Clinical Presentation}

Acute clinical radiation pneumonitis, heralded by dyspnea, low-grade fever, and dry cough, develops insidiously over 1-3 months after completion of radiation. Radiographic changes typically precede clinical symptoms, appearing 3-4 weeks following RT. Discrete ground-glass opacities, ill-defined patchy nodules, or consolidation with air bronchograms and volume loss within the irradiated field are common early findings which evolve over the ensuing 6-23 months, leaving a linear scar. Regional fibrosis is seen in nearly all patients, including those without clinical symptoms, and is characterized by the appearance of a well-demarcated area of volume loss, linear densities, bronchiectasis, retraction of the lung parenchyma, tenting and elevation of the hemidiaphragm, and ipsilateral pleural thickening within the irradiated field (Fig. 4). Post-radiation volume loss, bronchiectasis, and consolidation may occur following the newer modes of RT delivery but typically are less extensive than injury patterns following conventional radiation [107].

\section{Baseline}

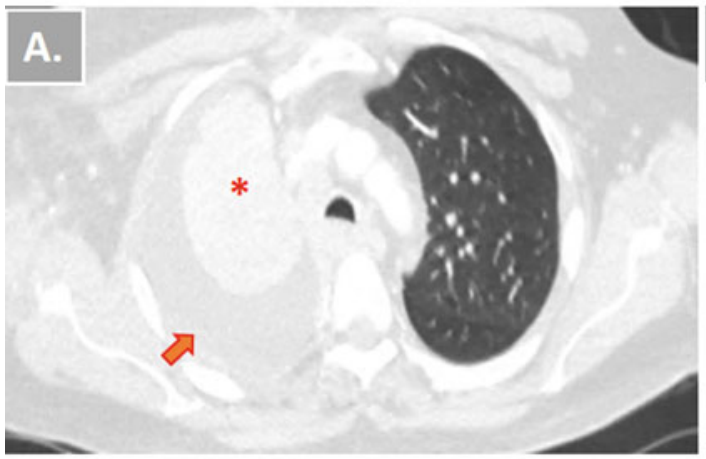

\section{9 weeks post XRT}

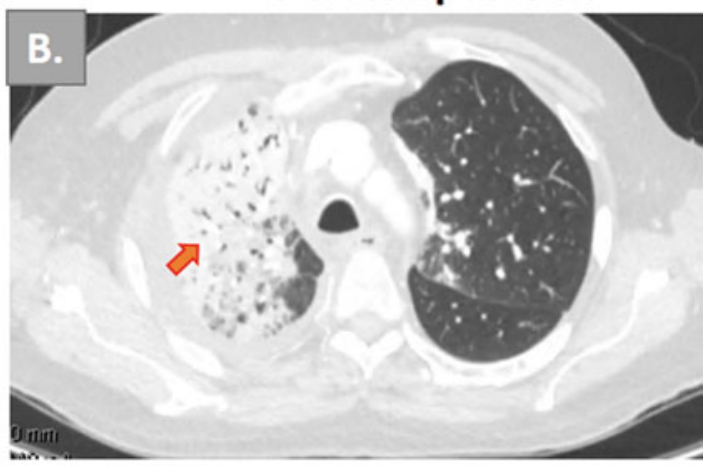

\section{6 weeks post XRT}

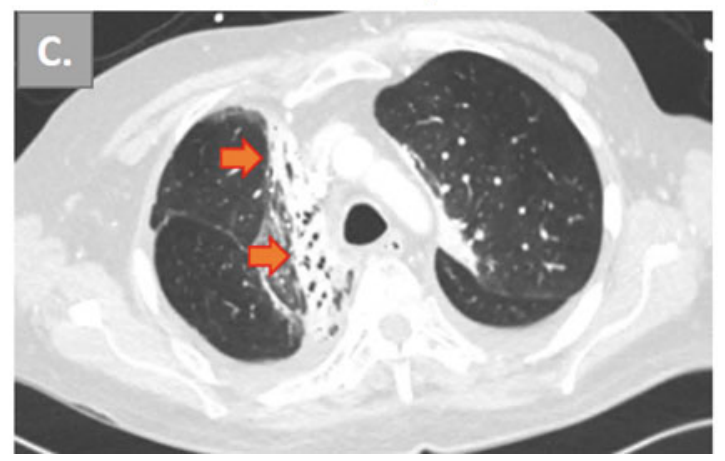

Fig. 4 Evolution of radiation-induced lung injury. A 56-year-old man underwent radiation therapy to the right upper and middle lobes and paramediastinal areas for primary bronchogenic carcinoma. At baseline, (a) a large central mass involving the right upper and middle lobes (*) along with a moderate-sized right pleural effusion (arrow) is seen. Nine weeks after completion of radiation therapy (b), there are dense consolidative opacities in the right lung (arrow), consistent with evolving radiation changes. The large mass-like consolidation has resolved. Nine months following completion of radiation therapy (c), linear densities outlining a well-demarcated area of volume loss (arrows), bronchiectasis, retraction of the lung parenchyma, and ipsilateral pleural thickening within the irradiated field are seen 


\section{Radiation Recall Pneumonitis}

Radiation recall pneumonitis (RRP) is a rare inflammatory reaction that develops within a previously irradiated field following certain chemotherapy and molecularly targeted therapies. This reaction has been most often observed following taxane- and anthracycline-based therapies. Gemcitabine, etoposide, vinorelbine, trastuzumab, and erlotinib may also trigger this disease [108, 109]. Clinically, RRP is signaled by dry cough, fever, and dyspnea and accompanied by ground-glass opacities and areas of consolidation that conform to the prior radiation treatment portal. RRP may develop during the first or subsequent course of therapy with the inciting agent, which may be weeks to years following completion of RT. Drug withdrawal and corticosteroid therapy may mitigate symptoms of radiation pneumonitis but have not been shown to be of benefit in the treatment of radiation fibrosis. Drug reintroduction has been successful in some cases [110].

\section{Other Manifestations of Radiation- Induced Lung Injury}

Pleural effusions may develop as early (within 6 months) and late (1-5 years) sequelae of RT. Effusions are typically small, ipsilateral, or bilateral. Reactive mesothelial cells with negative pleural fluid cytology are common. Most radiation-induced pleural effusions are asymptomatic, although pleuritic chest pain and dyspnea are occasionally presenting symptoms. Radiationrelated organizing pneumonia (OP) and eosinophilic pneumonia (EP) have been described in patients with breast cancer and may involve nonirradiated areas of the lung [107, 111]. These lung injury patterns are characterized by migratory pulmonary opacities that develop 1-3 months after completing RT. A prior history of asthma or atopy, coupled with blood or tissue eosinophilia, supports the diagnosis of radiation-induced EP. Both lung injury patterns are typically steroidresponsive.

\section{Management of Radiation-Induced Lung Injury}

Treatment recommendations for DILI in the cancer setting are generally provided by collective clinical experience and expert opinion. Pneumonitis grading schemes, based on the National Cancer Institute common terminology criteria for adverse events (NCI CTCAE) [112], offer limited guidelines for drug withdrawal and initiation of immunosuppressive therapies based on symptom severity. Permanent drug cessation is recommended for most DILI events associated with cytotoxic drugs; however, indications for drug interruption and resumption may vary with the specific class of agents in question. Resolution of pulmonary toxicity may occur following drug simple interruption in some patients. Thus, close follow-up while withholding corticosteroid therapy in asymptomatic patients with stable and mild disease is reasonable. Initiation of systemic corticosteroids is generally based on the acuity, severity, and rapidity of worsening of pulmonary impairment as well as the histopathologic patterns of disease. The benefits of corticosteroids in this setting are largely observational and gleaned from anecdotal reports and small case series. Evidencebased guidelines informing the optimal timing, dose, and duration of corticosteroid therapy do not exist. Prednisolone or its equivalent, dosed at $0.5-1 \mathrm{mg} / \mathrm{kg} /$ day, is typical, with dosing and tapering schedules guided by the radiologic and clinical symptoms and response to therapy. Additional therapies, such as cyclophosphamide, macrolides, cyclosporine, rituximab, and infliximab, may be indicated in steroid-refractory patients. Evidence favoring a benefit in these cases is also anecdotal and limited to small case series.

\section{References}

1. Bennett WM, Pastore L, Houghton DC. Fatal pulmonary bleomycin toxicity in cisplatin-induced acute renal failure. Cancer Treat Rep. 1980;64:921-4.

2. Azambuja E, Fleck JF, Batista RG, Menna SSB. Bleomycin lung toxicity: who are the patients with increased risk? Pulm Pharmacol Ther. 2005;18:363-6.

3. Massin F. Busulfan-induced pneumopathy. Rev Mal Respir. 1987;3:3-10. 
4. Barlesi F, Villani P, Doddoli C, Gimenez C, Kleisbauer JP. Gemcitabine-induced severe pulmonary toxicity. Fundam Clin Pharmacol. 2004;18:85-91.

5. Steijfer S. Bleomycin-induced pneumonitis. Chest. 2001;120:617-24.

6. Vulsteke C, Dierickx D, Verbeken E, Wolter P, Thomas J, Schoffski P. Rituximab-induced fatal interstitial pneumonitis: case report. Leuk Lymphoma. 2010;51:546-8.

7. Naidoo J, Wang X, Woo KM, Iyriboz T, Halpenny D, Cunningham J, Chaft JE, Segal NH, Callahan MK, Lesokhin AM, Rosenberg J, Voss MH, Rudin CM, Rizvi H, Hou X, Rodriguez K, Albano M, Gordon RA, Leduc C, Rekhtman N, Harris B, Menzies AM, Guminski AD, Carlino MS, Kong BY, Wolchok JD, Postow MA, Long GV, Hellmann MD. Pneumonitis in patients treated with anti-programmed death-1/programmed death ligand 1 therapy. J Clin Oncol. 2017;35:709-17.

8. Nishino M, Ramaiya NH, Hatabu H, Hodi FS, Armand PF. PD-1 inhibitor-related pneumonitis in lymphoma patients treated with single-agent pembrolizumab therapy. $\mathrm{Br} \mathrm{J}$ Haematol. 2016;180:752-5.

9. Mileshkin L, Prince HM, Rischin D, Zimet A. Severe interstitial pneumonitis following high-dose cyclophosphamide, thiotepa and docetaxel: two case reports and a review of the literature. Bone Marrow Transplant. 2001;27:559-63.

10. Herrmann J, Yang EH, Iliescu CA, Cilingiroglu M, Charitakis K, Hakeem A, Toutouzas K, Leesar MA, Grines CL, Marmagkiolis K. Vascular toxicities of cancer therapies: the old and the new - an evolving avenue. Circulation. 2016;133:1272-89.

11. Hedhli N, Russell KS. Cardiotoxicity of molecularly targeted agents. Curr Cardiol Rev. 2011;7:221-33.

12. Wattal S, Rao MS, Chandra GN, Razak UK, Shetty KR. Dasatinib induced cardiac tamponade-a rare association. J Clin Diagn Res. 2017;11:FD03-4.

13. Krauth MT, Herndlhofer S, Schmook MT, Mitterbauer-Hohendanner G, Schlogl E, Valent P. Extensive pleural and pericardial effusion in chronic myeloid leukemia during treatment with dasatinib at $100 \mathrm{mg}$ or $50 \mathrm{mg}$ daily. Haematologica. 2011;96:163-6.

14. Eskazan AE, Soysal T, Ongoren S, Gulturk E, Ferhanoglu B, Aydin Y. Pleural and pericardial effusions in chronic myeloid leukemia patients receiving low-dose dasatinib therapy. Haematologica. 2011;96: e15; author reply e16-17

15. Bergeron A, Rea D, Levy V, Picard C, Meignin V, Tamburini J, Bruzzoni-Giovanelli H, Calvo F, Tazi A, Rousselot P. Lung abnormalities after dasatinib treatment for chronic myeloid leukemia: a case series. Am J Respir Crit Care Med. 2007;176:814-8.

16. Montani D, Bergot E, Gunther S, Savale L, Bergeron A, Bourdin A, Bouvaist $\mathrm{H}$, Canuet $\mathrm{M}$, Pison C, Macro M, Poubeau P, Girerd B, Natali D, Guignabert C, Perros F, O'Callaghan DS, Jais X,
Tubert-Bitter P, Zalcman G, Sitbon O, Simonneau G, Humbert M. Pulmonary arterial hypertension in patients treated by dasatinib. Circulation. 2012;125:2128-37.

17. Wilcox BE, Ryu JH, Kalra S. Exacerbation of pre-existing interstitial lung disease after oxaliplatin therapy: a report of three cases. Respir Med. 2008;102:273-9.

18. Niho S, Kubota K, Goto K, Yoh K, Ohmatsu H, Kakinuma R, Saijo N, Nishiwaki Y. First-line single agent treatment with gefitinib in patients with advanced non-small-cell lung cancer: a phase II study. J Clin Oncol. 2006;24:64-9.

19. Liu V, White DA, Zakowski MF, Travis W, Kris MG, Ginsberg MS, Miller VA, Azzoli CG. Pulmonary toxicity associated with erlotinib. Chest. 2007;132:1042-4.

20. Saravanan V, Kelly CA. Reducing the risk of methotrexate pneumonitis in rheumatoid arthritis. Rheumatology (Oxford). 2004;43:143-7.

21. Vahid B, Marik PE. Pulmonary complications of novel antineoplastic agents for solid tumors. Chest. 2008;133:528-38.

22. Akoun G, Cadranel JL, Milleron BJ, D'Ortho MP, Mayaud CM. Bronchoalveolar lavage cell data in 19 patients with drug-associated pneumonitis (except amiodarone). Chest. 1991;99:98-104.

23. Stover DE, Zaman MB, Hajdu SI, Lange M, Gold J, Armstrong D. Bronchoalveolar lavage in the diagnosis of diffuse pulmonary infiltrates in the immunosuppressed host. Ann Intern Med. 1984;101:1-7.

24. White DA, Kris MG, Stover DE. Bronchoalveolar lavage cell populations in bleomycin lung toxicity. Thorax. 1987;42:551-2.

25. Beinert T, Düll T, Wolf K, Holler E, Vogelmeier C, Behr J, Kolb H. Late pulmonary impairment following allogeneic bone marrow transplantation. J Med Res. 1996;1:343-8.

26. van Barneveld $P$, Veenstra G, Sleijfer D, van der Mark T, Mulder N, Schraffordt Koops H, Sluiter H, Peset R. Changes in pulmonary function during and after bleomycin treatment in patients with testicular carcinoma. Cancer Chemother Pharmacol. 1985;14:168-71.

27. Gore EM, Lawton CA, Ash RC, Lipchik RJ. Pulmonary function changes in long-term survivors of bone marrow transplantation. Int $\mathrm{J}$ Radiat Oncol Biol Phys. 1996;36:67-75.

28. Theuws JC, Muller SH, Seppenwoolde Y, Kwa SL, Boersma LJ, Hart GA, Baas P, Lebesque JV. Effect of radiotherapy and chemotherapy on pulmonary function after treatment for breast cancer and lymphoma: a follow-up study. J Clin Oncol. 1999;17:3091-100.

29. Hirsch A, Vander Els N, Straus DJ, Gomez EG, Leung D, Portlock CS, Yahalom J. Effect of ABVD chemotherapy with and without mantle or mediastinal irradiation on pulmonary function and symptoms in early-stage Hodgkin's disease. J Clin Oncol. 1996;14:1297-305. 
30. Bruno B, Souillet G, Bertrand Y, Werck-Gallois MC, So Satta A, Bellon G. Effects of allogeneic bone marrow transplantation on pulmonary function in 80 children in a single paediatric centre. Bone Marrow Transplant. 2004;34:143-7.

31. Hasleton PS, O’Driscoll BR, Lynch P, Webster A, Kalra SJ, Gattamaneini HR, Woodcock AA, Poulter LW. Late BCNU lung: a light and ultrastructural study on the delayed effect of BCNU on the lung parenchyma. J Pathol. 1991;164:31-6.

32. O'Driscoll BR, Hasleton PS, Taylor PM, Poulter LW, Gattameneni HR, Woodcock AA. Active lung fibrosis up to 17 years after chemotherapy with carmustine (BCNU) in childhood. $\mathrm{N}$ Engl $\mathrm{J}$ Med. 1990;323:378-82.

33. Beynat-Mouterde C, Beltramo G, Lezmi G, Pernet D, Camus C, Fanton A, Foucher P, Cottin V, Bonniaud P. Pleuroparenchymal fibroelastosis as a late complication of chemotherapy agents. Eur Respir J. 2014;44:523-7.

34. Akira M, Inoue Y, Kitaichi M, Yamamoto S, Arai T, Toyokawa K. Usual interstitial pneumonia and nonspecific interstitial pneumonia with and without concurrent emphysema: thin-section CT findings. Radiology. 2009;251:271-9.

35. Cordier JF. Organising pneumonia. Thorax. 2000;55:318-28.

36. Drakopanagiotakis F, Paschalaki K, Abu-Hijleh M, Aswad B, Karagianidis N, Kastanakis E, Braman SS, Polychronopoulos V. Cryptogenic and secondary organizing pneumonia: clinical presentation, radiographic findings, treatment response, and prognosis. Chest. 2011;139:893-900.

37. Raanani P, Segal E, Levi I, Bercowicz M, Berkenstat H, Avigdor A, Perel A, Ben-Bassat I. Diffuse alveolar hemorrhage in acute promyelocytic leukemia patients treated with ATRA - a manifestation of the basic disease or the treatment. Leuk Lymphoma. 2000;37:605-10.

38. Tefferi A, Litzow MR, Pardanani A. Long-term outcome of treatment with ruxolitinib in myelofibrosis. $\mathrm{N}$ Engl J Med. 2011;365:1455-7.

39. Beauverd Y, Samii K. Acute respiratory distress syndrome in a patient with primary myelofibrosis after ruxolitinib treatment discontinuation. Int $\mathrm{J}$ Hematol. 2014;100:498-501.

40. Rogers JE, Yang D. Differentiation syndrome in patients with acute promyelocytic leukemia. J Oncol Pharm Pract. 2012;18:109-14.

41. Luesink M, Jansen JH. Advances in understanding the pulmonary infiltration in acute promyelocytic leukaemia. Br J Haematol. 2010;151:209-20.

42. Cooper J. Drug-induced lung disease. Adv Intern Med. 1997;42:231-68.

43. Shannon V, Price K. Pulmonary complications of cancer therapy. Anesthesiol Clin North Am. 1998;16:563-85.
44. Sachdeva A, Matuschak GM. Diffuse alveolar hemorrhage following alemtuzumab. Chest. 2008; 133:1476-8.

45. Hildebrand F, Rosenow EI, Haberman T. Pulmonary complications of leukemia. Chest. 1990;98(5):1233-9.

46. Afessa B, Tefferi A, Litzow MR, Krowka MJ, Wylam ME, Peters SG. Diffuse alveolar hemorrhage in hematopoietic stem cell transplant recipients. Am J Respir Crit Care Med. 2002;166:641-5.

47. Sandler A. Bevacizumab in non small cell lung cancer. Clin Cancer Res. 2007;13:s4613-6.

48. Johnson DH, Fehrenbacher L, Novotny WF, Herbst RS, Nemunaitis JJ, Jablons DM, Langer CJ, DeVore RF 3rd, Gaudreault J, Damico LA, Holmgren E, Kabbinavar F. Randomized phase II trial comparing bevacizumab plus carboplatin and paclitaxel with carboplatin and paclitaxel alone in previously untreated locally advanced or metastatic non-smallcell lung cancer. J Clin Oncol. 2004;22:2184-91.

49. Huggins JT, Sahn SA. Drug-induced pleural disease. Clin Chest Med. 2004;25:141-53.

50. Wohlrab J, Liu M, Anderson E, Kia Noury D. Docetaxel induced pleural effusions [abstract]. Chest. 2002;122:94S-5S.

51. Procopio G, Verzoni E, Gevorgyan A, Mancin M, Pusceddu S, Catena L, Platania M, Guadalupi V, Martinetti A, Bajetta E. Safety and activity of sorafenib in different histotypes of advanced renal cell carcinoma. Oncology. 2007;73:204-9.

52. Nalluri SR, Chu D, Keresztes R, Zhu X, Wu S. Risk of venous thromboembolism with the angiogenesis inhibitor bevacizumab in cancer patients: a metaanalysis. JAMA. 2008;300:2277-85.

53. Godinas L, Guignabert C, Seferian A, Perros F, Bergot E, Sibille Y, Humbert M, Montani D. Tyrosine kinase inhibitors in pulmonary arterial hypertension: a double-edge sword? Semin Respir Crit Care Med. 2013;34:714-24.

54. Abratt RP, Morgan GW. Lung toxicity following chest irradiation in patients with lung cancer. Lung Cancer. 2002;35:103-9.

55. Soultati A, Mountzios G, Avgerinou C, Papaxoinis G, Pectasides D, Dimopoulos MA, Papadimitriou C. Endothelial vascular toxicity from chemotherapeutic agents: preclinical evidence and clinical implications. Cancer Treat Rev. 2012;38:473-83.

56. Szebeni J, Alving CR, Savay S, Barenholz Y, Priev A, Danino D, Talmon Y. Complement activation-related pseudoallergy caused by liposomes, micellar carriers of intravenous drugs, and radiocontrast agents. Formation of complement-activating particles in aqueous solutions of Taxol: possible role in hypersensitivity reactions. Crit Rev Ther Drug Carrier Syst. 2001;18:567-606.

57. Lv Y, Tang B, Liu X, Xue C, Liu Y, Kang P, Zhang LA. Comparative study of scientific publications in health care sciences and services from Mainland China, Taiwan, Japan, and India (2007-2014). Int J Environ Res Public Health. 2016;13:79. 
58. Markman M. Managing taxane toxicities. Support Care Cancer. 2003;11:144-7.

59. Rivera NP, Kris MG, Gralla RJ. Syndrome of acute dyspnea related to combined mitomycin plus vinca alkaloid chemotherapy. Am J Clin Oncol. 1995; 18:245-50.

60. Hwang SD, Chung BH, Oh EJ, Choi BS, Park CW, Kim YS, Yang CW. Effect of pretransplant rituximab use on posttransplant clinical outcomes in patients with high panel reactive antibody scores. Nephron. 2015;130:239-44.

61. Voog E, Morschhauser F, Solal-Celigny P. Neutropenia in patients treated with rituximab. N Engl J Med. 2003;348:2691-4; discussion 2691-2694

62. Byrd JC, Peterson BL, Morrison VA, Park K, Jacobson R, Hoke E, Vardiman JW, Rai K, Schiffer CA, Larson RA. Randomized phase 2 study of fludarabine with concurrent versus sequential treatment with rituximab in symptomatic, untreated patients with B-cell chronic lymphocytic leukemia: results from Cancer and Leukemia Group B 9712 (CALGB 9712). Blood. 2003;101:6-14.

63. Hillmen P, Robak T, Janssens A, Babu KG, Kloczko J, Grosicki S, Doubek M, Panagiotidis P, Kimby E, Schuh A, Pettitt AR, Boyd T, Montillo M, Gupta IV, Wright O, Dixon I, Carey JL, Chang CN, Lisby S, McKeown A, Offner F, Investigators CS. Chlorambucil plus ofatumumab versus chlorambucil alone in previously untreated patients with chronic lymphocytic leukaemia (COMPLEMENT 1): a randomised, multicentre, open-label phase 3 trial. Lancet. 2015;385:1873-83.

64. Keating MJ, O'Brien S, Albitar M, Lerner S, Plunkett W, Giles F, Andreeff M, Cortes J, Faderl S, Thomas D, Koller C, Wierda W, Detry MA, Lynn A, Kantarjian H. Early results of a chemoimmunotherapy regimen of fludarabine, cyclophosphamide, and rituximab as initial therapy for chronic lymphocytic leukemia. J Clin Oncol. 2005;23:4079-88.

65. Martin SI, Marty FM, Fiumara K, Treon SP, Gribben JG, Baden LR. Infectious complications associated with alemtuzumab use for lymphoproliferative disorders. Clin Infect Dis. 2006;43:16-24.

66. Garcia $\mathrm{CA}, \mathrm{Wu} \mathrm{S}$. Attributable risk of infection to mTOR inhibitors everolimus and temsirolimus in the treatment of cancer. Cancer Investig. 2016;34:521-30.

67. Zelenetz AD, Barrientos JC, Brown JR, Coiffier B, Delgado J, Egyed M, Ghia P, Illes A, Jurczak W, Marlton P, Montillo M, Morschhauser F, Pristupa AS, Robak T, Sharman JP, Simpson D, Smolej L, Tausch E, Adewoye AH, Dreiling LK, Kim Y, Stilgenbauer S, Hillmen P. Idelalisib or placebo in combination with bendamustine and rituximab in patients with relapsed or refractory chronic lymphocytic leukaemia: interim results from a phase 3, randomised, double-blind, placebo-controlled trial. Lancet Oncol. 2017;18:297-311.
68. O’Brien SM, Lamanna N, Kipps TJ, Flinn I, Zelenetz AD, Burger JA, Keating M, Mitra S, Holes L, Yu AS, Johnson DM, Miller LL, Kim Y, Dansey RD, Dubowy RL, Coutre SE. A phase 2 study of idelalisib plus rituximab in treatment-naive older patients with chronic lymphocytic leukemia. Blood. 2015;126:2686-94.

69. Jones JA, Robak T, Brown JR, Awan FT, Badoux X, Coutre S, Loscertales J, Taylor K, Vandenberghe E, Wach M, Wagner-Johnston N, Ysebaert L, Dreiling L, Dubowy R, Xing G, Flinn IW, Owen C. Efficacy and safety of idelalisib in combination with ofatumumab for previously treated chronic lymphocytic leukaemia: an open-label, randomised phase 3 trial. Lancet Haematol. 2017;4:e114-26.

70. Stilgenbauer S, Eichhorst B, Schetelig J, Coutre S, Seymour JF, Munir T, Puvvada SD, Wendtner CM, Roberts AW, Jurczak W, Mulligan SP, Bottcher S, Mobasher M, Zhu M, Desai M, Chyla B, Verdugo M, Enschede SH, Cerri E, Humerickhouse R, Gordon G, Hallek M, Wierda WG. Venetoclax in relapsed or refractory chronic lymphocytic leukaemia with $17 \mathrm{p}$ deletion: a multicentre, open-label, phase 2 study. Lancet Oncol. 2016;17:768-78.

71. Wysham NG, Sullivan DR, Allada G. An opportunistic infection associated with ruxolitinib, a novel janus kinase 1,2 inhibitor. Chest. 2013;143:1478-9.

72. Palandri F, Polverelli N, Breccia M, Nicolino B, Vitolo U, Alimena G, Cavo M, Vianelli N, Benevolo $\mathrm{G}$. Safety and efficacy of ruxolitinib in myelofibrosis patients without splenomegaly. $\mathrm{Br} \mathrm{J}$ Haematol. 2016;174:160-2.

73. Heine A, Brossart P, Wolf D. Ruxolitinib is a potent immunosuppressive compound: is it time for antiinfective prophylaxis? Blood. 2013;122:3843-4.

74. Offidani M, Corvatta L, Polloni C, Gentili S, Brioni A, Visani G, Galieni P, Brunori M, Alesiani F, Catarini M, Centurioni R, Samori A, Blasi N, Ferranti M, Fraticelli P, Mele A, Rizzi R, Larocca F, Leoni P. Infectious complications in patients with multiple myeloma treated with new drug combinations containing thalidomide. Leuk Lymphoma. 2011;52:776-85.

75. Teh BW, Harrison SJ, Worth LJ, Thursky KA, Slavin MA. Infection risk with immunomodulatory and proteasome inhibitor-based therapies across treatment phases for multiple myeloma: a systematic review and meta-analysis. Eur J Cancer. 2016;67:21-37.

76. Jouanguy E, Altare F, Lamhamedi S, Revy P, Emile JF, Newport M, Levin M, Blanche S, Seboun E, Fischer A, Casanova JL. Interferon-gamma-receptor deficiency in an infant with fatal bacille CalmetteGuerin infection. N Engl J Med. 1996;335:1956-61.

77. Keane J, Gershon S, Wise RP, Mirabile-Levens E, Kasznica J, Schwieterman WD, Siegel JN, Braun MM. Tuberculosis associated with infliximab, a tumor necrosis factor alpha-neutralizing agent. $\mathrm{N}$ Engl J Med. 2001;345:1098-104.

78. Sakai S, Kauffman KD, Sallin MA, Sharpe AH, Young HA, Ganusov VV, Barber DL. CD4 T cell- 
derived IFN-gamma plays a minimal role in control of pulmonary Mycobacterium tuberculosis infection and must be actively repressed by PD-1 to prevent lethal disease. PLoS Pathog. 2016;12:e1005667.

79. Hadjiliadis D, Govert JA. Methemoglobinemia after infusion of ifosfamide chemotherapy: first report of a potentially serious adverse reaction related to ifosfamide. Chest. 2000;118:1208-10.

80. Abdel-Rahman O, Fouad M. Risk of pneumonitis in cancer patients treated with immune checkpoint inhibitors: a meta-analysis. Ther Adv Respir Dis. 2016;10:183-93.

81. Zimmer L, Goldinger SM, Hofmann L, Loquai C, Ugurel S, Thomas I, Schmidgen MI, Gutzmer R, Utikal JS, Goppner D, Hassel JC, Meier F, Tietze JK, Forschner A, Weishaupt C, Leverkus M, Wahl R, Dietrich U, Garbe C, Kirchberger MC, Eigentler T, Berking C, Gesierich A, Krackhardt AM, Schadendorf D, Schuler G, Dummer R, Heinzerling LM. Neurological, respiratory, musculoskeletal, cardiac and ocular side-effects of anti-PD-1 therapy. Eur J Cancer. 2016;60:210-25.

82. Nishino M, Giobbie-Hurder A, Hatabu H, Ramaiya $\mathrm{NH}$, Hodi FS. Incidence of programmed cell death 1 inhibitor-related pneumonitis in patients with advanced cancer: a systematic review and metaanalysis. JAMA Oncol. 2016;2:1607-16.

83. Eigentler TK, Hassel JC, Berking C, Aberle J, Bachmann O, Grunwald V, Kahler KC, Loquai C, Reinmuth N, Steins M, Zimmer L, Sendl A, Gutzmer R. Diagnosis, monitoring and management of immune-related adverse drug reactions of anti-PD-1 antibody therapy. Cancer Treat Rev. 2016;45:7-18.

84. Nishino M, Brais LK, Brooks NV, Hatabu H, Kulke $\mathrm{MH}$, Ramaiya NH. Drug-related pneumonitis during mammalian target of rapamycin inhibitor therapy in patients with neuroendocrine tumors: a radiographic pattern-based approach. Eur J Cancer. 2016;53:163-70.

85. Nishino M, Chambers ES, Chong CR, Ramaiya NH, Gray SW, Marcoux JP, Hatabu H, Janne PA, Hodi FS, Awad MM. Anti-PD-1 inhibitor-related pneumonitis in non-small cell lung cancer. Cancer Immunol Res. 2016;4:289-93.

86. Nishino M, Ramaiya NH, Awad MM, Sholl LM, Maattala JA, Taibi M, Hatabu H, Ott PA, Armand PF, Hodi FS. PD-1 inhibitor-related pneumonitis in advanced cancer patients: radiographic patterns and clinical course. Clin Cancer Res. 2016;22:6051-60.

87. Balaji A, Verde F, Suresh K, Naidoo J. Pneumonitis from anti-PD-1/PD-L1 therapy. Oncology (Williston Park). 2017;31:739-46, 754

88. Nishino M, Hatabu H. Programmed death-1/ programmed death ligand-1 inhibitor-related pneumonitis and radiographic patterns. J Clin Oncol. 2017;35:1628-9.

89. Lomax AJ, McGuire HM, McNeil C, Choi CJ, Hersey P, Karikios D, Shannon K, van Hal S, Carr U, Crotty A, Gupta SK, Hollingsworth J,
Kim H, Fazekas de St Groth B, McGill $\mathrm{N}$. Immunotherapy-induced sarcoidosis in patients with melanoma treated with PD-1 checkpoint inhibitors: case series and immunophenotypic analysis. Int $\mathrm{J}$ Rheum Dis. 2017;20:1277-85.

90. Berthod G, Lazor R, Letovanec I, Romano E, Noirez L, Mazza Stalder J, Speiser DE, Peters S, Michielin O. Pulmonary sarcoid-like granulomatosis induced by ipilimumab. J Clin Oncol. 2012;30: e156-9.

91. Gounant V, Brosseau S, Naltet C, Opsomer MA, Antoine M, Danel C, Khalil A, Cadranel J, Zalcman G. Nivolumab-induced organizing pneumonitis in a patient with lung sarcomatoid carcinoma. Lung Cancer. 2016;99:162-5.

92. Kolla BC, Patel MR. Recurrent pleural effusions and cardiac tamponade as possible manifestations of pseudoprogression associated with nivolumab therapy- a report of two cases. J Immunother Cancer. 2016;4:80.

93. Chiou VL, Burotto M. Pseudoprogression and immune-related response in solid tumors. J Clin Oncol. 2015;33:3541-3.

94. Champiat S, Lambotte O, Barreau E, Belkhir R, Berdelou A, Carbonnel F, Cauquil C, Chanson P, Collins M, Durrbach A, Ederhy S, Feuillet S, Francois H, Lazarovici J, Le Pavec J, De Martin E, Mateus C, Michot JM, Samuel D, Soria JC, Robert C, Eggermont A, Marabelle A. Management of immune checkpoint blockade dysimmune toxicities: a collaborative position paper. Ann Oncol. 2016;27:559-74.

95. Kluetz PG, Chingos DT, Basch EM, Mitchell SA. Patient-reported outcomes in cancer clinical trials: measuring symptomatic adverse events with the National Cancer Institute's patient-reported outcomes version of the common terminology criteria for adverse events (PRO-CTCAE). Am Soc Clin Oncol Educ Book. 2016;35:67-73.

96. Barrett DM, Teachey DT, Grupp SA. Toxicity management for patients receiving novel T-cell engaging therapies. Curr Opin Pediatr. 2014;26:43-9.

97. Grupp SA, Kalos M, Barrett D, Aplenc R, Porter DL, Rheingold SR, Teachey DT, Chew A, Hauck B, Wright JF, Milone MC, Levine BL, June $\mathrm{CH}$. Chimeric antigen receptor-modified $\mathrm{T}$ cells for acute lymphoid leukemia. $\mathrm{N}$ Engl J Med. 2013;368:1509-18.

98. Barrett DM, Singh N, Porter DL, Grupp SA, June $\mathrm{CH}$. Chimeric antigen receptor therapy for cancer. Annu Rev Med. 2014;65:333-47.

99. Maude SL, Frey N, Shaw PA, Aplenc R, Barrett DM, Bunin NJ, Chew A, Gonzalez VE, Zheng Z, Lacey SF, Mahnke YD, Melenhorst JJ, Rheingold SR, Shen A, Teachey DT, Levine BL, June CH, Porter DL, Grupp SA. Chimeric antigen receptor T cells for sustained remissions in leukemia. N Engl J Med. 2014;371:1507-17.

100. Maude SL, Teachey DT, Porter DL, Grupp SA. CD19-targeted chimeric antigen receptor T-cell 
therapy for acute lymphoblastic leukemia. Blood. 2015; 125:4017-23.

101. Porter DL, Levine BL, Kalos M, Bagg A, June $\mathrm{CH}$. Chimeric antigen receptor-modified $\mathrm{T}$ cells in chronic lymphoid leukemia. $N$ Engl $J$ Med. 2011;365:725-33.

102. Brentjens RJ, Riviere I, Park JH, Davila ML, Wang X, Stefanski J, Taylor C, Yeh R, Bartido S, BorquezOjeda O, Olszewska M, Bernal Y, Pegram H, Przybylowski M, Hollyman D, Usachenko Y, Pirraglia D, Hosey J, Santos E, Halton E, Maslak P, Scheinberg D, Jurcic J, Heaney M, Heller G, Frattini M, Sadelain M. Safety and persistence of adoptively transferred autologous CD19-targeted T cells in patients with relapsed or chemotherapy refractory B-cell leukemias. Blood. 2011;118:4817-28.

103. Fitzgerald JC, Weiss SL, Maude SL, Barrett DM, Lacey SF, Melenhorst JJ, Shaw P, Berg RA, June CH, Porter DL, Frey NV, Grupp SA, Teachey DT. Cytokine release syndrome after chimeric antigen receptor T cell therapy for acute lymphoblastic leukemia. Crit Care Med. 2017;45:e124-31.

104. Teachey DT, Rheingold SR, Maude SL, Zugmaier G, Barrett DM, Seif AE, Nichols KE, Suppa EK, Kalos M, Berg RA, Fitzgerald JC, Aplenc R, Gore L, Grupp SA. Cytokine release syndrome after blinatumomab treatment related to abnormal macrophage activation and ameliorated with cytokinedirected therapy. Blood. 2013;121:5154-7.

105. Marks LB, Yu X, Vujaskovic Z, Small W Jr, Folz R, Anscher MS. Radiation-induced lung injury. Semin Radiat Oncol. 2003;13:333-45.

106. Movsas B, Raffin TA, Epstein AH, Link CJ Jr. Pulmonary radiation injury. Chest. 1997; 111:1061-76.

107. Cornelissen R, Senan S, Antonisse IE, Liem H, Tan YK, Rudolphus A, Aerts JG. Bronchiolitis obliterans organizing pneumonia (BOOP) after thoracic radiotherapy for breast carcinoma. Radiat Oncol. 2007;2:1-5.
108. Schweitzer V, Juillard G, Bajada C. Radiation recall dermatitis and pneumonitis in a patient treated with paclitaxel. Cancer. 1995;76:1069-72.

109. Schwarte S, Wagner K, Karstens JH, Bremer M. Radiation recall pneumonitis induced by gemcitabine. Strahlenther Onkol. 2007;183:215-7.

110. Ding X, Ji W, Li J, Zhang X, Wang L. Radiation recall pneumonitis induced by chemotherapy after thoracic radiotherapy for lung cancer. Radiat Oncol. 2011;6:1-6.

111. Cottin V, Frognier R, Monnot H, Levy A, DeVuyst P, Cordier JF, Pulmonaires. GdEedRsIMO. Chronic eosinophilic pneumonia after radiation therapy for breast cancer. Eur Respir J. 2004;23:9-13.

112. Hagelstein V, Ortland I, Wilmer A, Mitchell SA, Jaehde U. Validation of the German patient-reported outcomes version of the common terminology criteria for adverse events (PRO-CTCAE). Ann Oncol. 2016;27:2294-9.

113. Gafter-Gvili A, Gurion R, Raanani P, Shpilberg O, Vidal L. Bendamustine-associated infections-systematic review and meta-analysis of randomized controlled trials. Hematol Oncol. 2017;35(4):424-431. https://www.ncbi.nlm.nih.gov/pubmed/27734524.

114. Ravandi F, O'Brien S. Infections associated with purine analogs and monoclonal antibodies.Blood Rev. 2005;19(5):253-73. https://www.ncbi.nlm.nih. gov/pubmed/15963834.

115. Dias AL, Jain D. Ibrutinib: a new frontier in the treatment of chronic lymphocytic leukemia by Bruton's tyrosine kinase inhibition. Cardiovasc Hematol Agents Med Chem. 2013;11(4):265-71. https://www.ncbi.nlm.nih.gov/pubmed/24433470.

116. Teh BW, Harrison SJ, Worth LJ, Thursky KA, Slavin MA. Infection risk with immunomodulatory and proteasome inhibitor-based therapies across treatment phases for multiple myeloma: A systematic review and meta-analysis. Eur J Cancer. 2016;67:21-37. https://doi.org/10.1016/j.ejca.2016.07.025. https:// www.ncbi.nlm.nih.gov/pubmed/27592069. 